\title{
Low biodegradability of particulate organic carbon mobilized from thaw slumps on the Peel Plateau, NT, and possible chemosynthesis and sorption effects
}

\author{
Sarah Shakil $^{1}$, Suzanne E. Tank ${ }^{1}$, Jorien E. Vonk ${ }^{2}$, Scott Zolkos ${ }^{1,3}$
}

$5 \quad{ }^{1}$ Department of Biological Sciences, University of Alberta, Edmonton, Canada ${ }^{2}$ Department of Earth Sciences, Vrije Universiteit, Amsterdam, The Netherlands ${ }^{3}$ current address: John A. Paulson School of Engineering and Applied Sciences, Harvard University, Cambridge, MA, 02138, USA

10 Correspondence to: Sarah Shakil (shakil@ualberta.ca) 
https://doi.org/10.5194/bg-2021-150

Preprint. Discussion started: 2 July 2021

(c) Author(s) 2021. CC BY 4.0 License.

Abstract. Upon thaw, permafrost carbon entering streams may be mineralized into $\mathrm{CO}_{2}$ or re-sequestered into sediments. The balance between these processes is an important uncertainty in the permafrost-carbon-climate feedback. Warming and wetting in the western Canadian Arctic are accelerating thaw-driven mass wasting by permafrost thaw slumps, increasing particulate organic carbon (POC) delivered to headwater streams by orders of magnitude. Using aerobic incubations of POC from streams

15 affected by thaw slumps we find that slump-mobilized POC undergoes minimal ( 4\%) oxidation over a 1-month period and may be predominantly destined for sediment deposition. Mobilization of mineral-rich tills in this region may also protect carbon from mineralization via adsorption to minerals and promote inorganic carbon sequestration via chemolithoautotrophic processes. Region-specific assessments of permafrost carbon fates and inquiries beyond organic carbon decomposition are needed to constrain drivers of carbon cycling and climate feedbacks within stream networks affected by permafrost thaw.

\section{Introduction}

Permafrost soils comprise the single largest pool of terrestrial organic carbon (OC) (Schuur et al., 2015; Hugelius et al., 2014), half of which may be vulnerable to rapid mobilization into modern biogeochemical cycles via abrupt thaw processes (Turetsky et al., 2020; Olefeldt et al., 2016). Permafrost dissolved organic carbon (DOC), typically defined as compounds $<0.7 \mu \mathrm{m}$, is highly susceptible to biotic mineralization into $\mathrm{CO}_{2}$ within aquatic systems (Vonk et al., 2015a; Littlefair and Tank, 2018;

25 Abbott et al., 2014; Mann et al., 2015). Abrupt thaw can mobilize orders of magnitude more particulate organic carbon (POC, typically $>0.7 \mu \mathrm{m}$ ) than DOC, yet the biodegradability of permafrost POC is not well understood (Shakil et al., 2020; Tank et al., 2020; Vonk et al., 2015b). Suspended particles can be important sites for mineralization (Attermeyer et al., 2018) or mineral protection (Hemingway et al., 2019; Opfergelt, 2020; Groeneveld et al., 2020). In addition to molecular composition and a host of environmental factors that typically affect organic matter decomposition (e.g., microbial activity, nutrient availability)

30 (Kothawala et al., 2021), mineralization of POC in stream networks depends on transport vs. deposition within those networks. When settled out, mineralization of POC can be reduced by $~ 50 \%$ (Richardson et al., 2013) or more, particularly if contained in anoxic sediments (Peter et al., 2016). Fractions of POC with different density and size therefore not only experience a different settling and transport trajectory, but also may have differing processes and rates affecting OC dynamics (Tesi et al., 2016). If biodegradability varies across size and density fractions, this could alter realized mineralization during transport

35 relative to measurements on bulk OC (Tesi et al., 2016).

Warming and intensifying precipitation across the ice-rich terrain of the Peel Plateau in western Canada has triggered an acceleration of thaw-driven landscape erosion in the form of retrogressive thaw slumps (hereafter, slumps) (Kokelj et al., 2020). Slump-DOC in the region has an elevated lability compared to reference streams without slumps, as shown by chemical composition and incubations (Littlefair et al., 2017; Littlefair and Tank, 2018). Slump-POC chemical composition suggests

40 lower bioavailability (Shakil et al., 2020; Bröder et al., 2021), though POC bioavailability has not been experimentally assessed. Given that slump-released carbon occurs almost entirely as POC in this region (Shakil et al., 2020), understanding the fate of this carbon remains a critical knowledge gap. 
https://doi.org/10.5194/bg-2021-150

Preprint. Discussion started: 2 July 2021

(c) Author(s) 2021. CC BY 4.0 License.

(c) (i)

Discussions

Our objectives were to assess the potential for slump POC to be mineralized to $\mathrm{CO}_{2}$ during transport in streams. To do this, we undertook experimental incubations to: (a) determine whether slump-POC differs in biodegradability from POC present in unimpacted waters; and (b) quantify and assess the biodegradability of slump-POC fractions relative to their transport potential. This work provides insight into the fate of an understudied component of permafrost-mobilized OC.

\section{Methods}

\subsection{Region and field sampling}

Slumping across the Peel Plateau (Fig. 1) typically mobilizes terrestrial material from three distinct sources: (1) Pleistocene-

50 age tills that have remained preserved within permafrost since deposition by the Laurentide Ice Sheet and subsequent permafrost aggradation; (2) Holocene-age permafrost developed from tills following active layer deepening and/or slumping in previous warm periods; and (3) a contemporary active layer. Thus, relative contribution of sources to streams can depend on thaw depth (Shakil et al., 2020; Bröder et al., 2021). Variation in source composition can also vary west-east as vegetation (elevation) and geology changes along this gradient (Shakil et al., 2020).

55 Sampling occurred during July-August, within the Stony Creek and Vittrekwa River watersheds of the Gwich'in Settlement Region on the Peel Plateau (Fig. 1). In 2015, substrate from streams near and within three slump sites was used to test if mobilization of slump-POC and nutrient release affect biodegradability of OC in streams (Shakil et al., 2020). Stream water samples were obtained from: channelized runoff within each thaw slump (IN); a downstream location where all runoff entered the valley-bottom stream (DN); and an unimpacted reference stream upstream of slump inflow (UP) (Fig. 1b). Site HD-UP experienced some encroachment of slump runoff, and thus was not a fully unimpacted site (Fig. S5). In 2016, substrate was collected upstream, within, immediately downstream, and $2.79 \mathrm{~km}$ downstream of slump SE to assess variations in biodegradability with transport potential. In 2019, substrate was collected within and downstream of slump FM3 to follow-up results from 2015 and 2016 (details below). Slump sites had varied elevation and morphology, with maximum headwall heights (Fig. 1a) ranging from 7.1 to $23 \mathrm{~m}$ (Shakil et al., 2020). For further sample collection details, see supplementary S1. 
https://doi.org/10.5194/bg-2021-150

Preprint. Discussion started: 2 July 2021

(c) Author(s) 2021. CC BY 4.0 License.

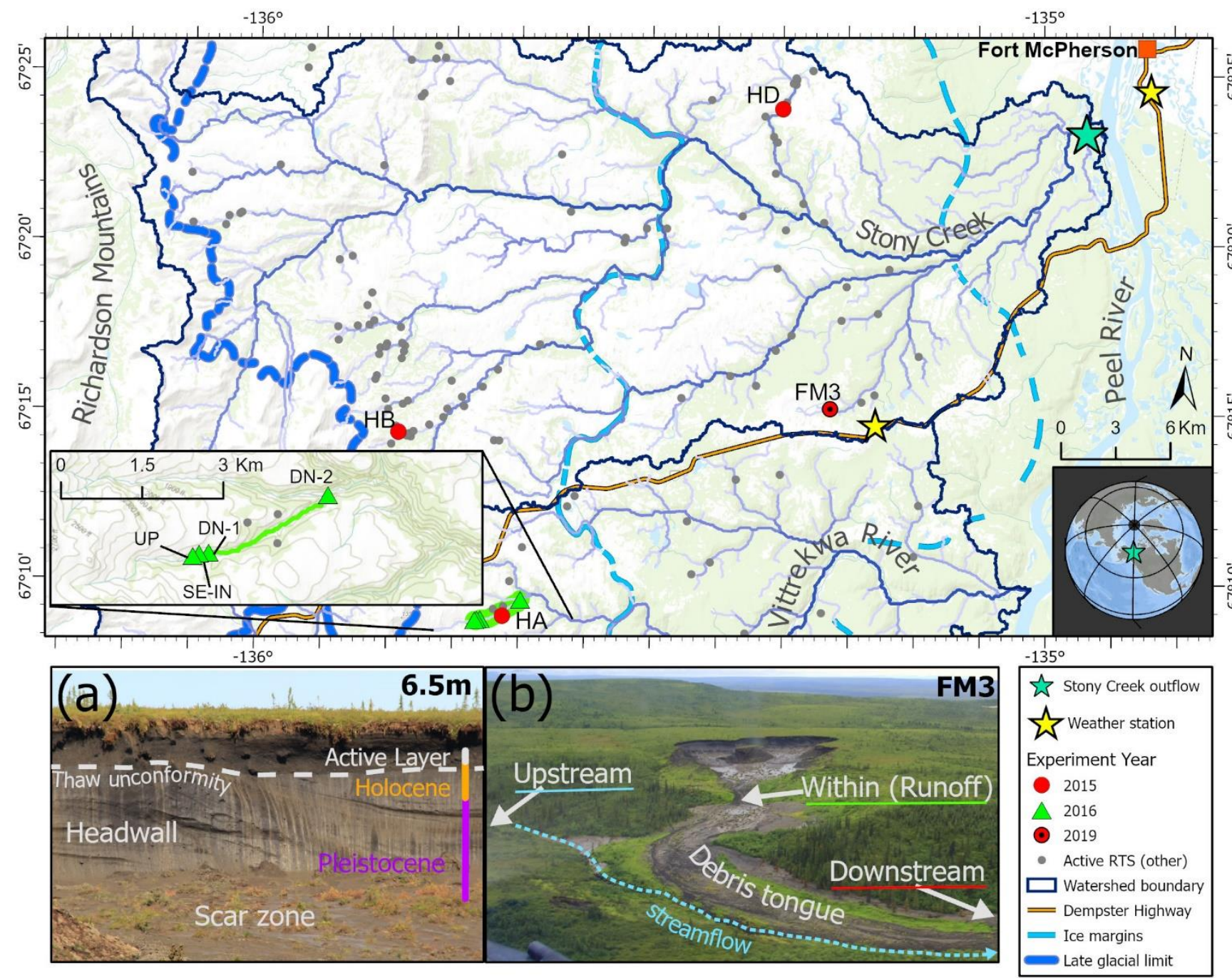

Figure 1: Location of slump sites sampled for experiments. 2016 sampling points (green triangles) show sampling locations along a transect which began just upstream of the point where slump SE runoff enters a valley bottom stream. Watershed boundary in inset is of the Peel River Watershed with the Stony Creek outflow marked for reference. Panel (a) shows headwall units of a slump. Panel (b) shows stream sampling points relative to a slump site. Active RTS features are from Segal et al. (2016). Former glacial limits of the Laurentide Ice Sheet (ice margins and late-glacial limit) are delineated from Duk-Rodkin and Hughes (1992). Service Layer credits: (1) World Topographic Map: Northwest Territories, ESRI, () OpenStreetMap contributors, HERE, Garmin, USGS, NGA, EPA, USDA, NPS, AAFC, NRCan. (2) World Ocean Base: Esri, Garmin, GEBCO, NOAA NGDC, and other contributors. (3) World Continents. 
https://doi.org/10.5194/bg-2021-150

Preprint. Discussion started: 2 July 2021

(c) Author(s) 2021. CC BY 4.0 License.

(c) (i)

\subsection{Biodegradation experiments}

\subsubsection{Experiment: Effects of POC source, dissolved constituents, and settling}

To test the effect of POC source (Table 1), we incubated unfiltered upstream water (upstream POC; treatment "UU") and filtered upstream water with a $2 \mathrm{~mL}$ addition of slump runoff (slump POC; "SU") in $120 \mathrm{~mL}$ glass serum bottles for 7 days at ca. $20^{\circ} \mathrm{C}$ in the dark, with continuous end-over-end rotation (4 rpm) (supplementary S2, Fig. S5). Control bottles accounted for DOC contained in filtered upstream water alone (no POC control; "UF"). Additionally, we tested for: (a) the effect of particle deposition by allowing a replicate set of SU bottles to settle out ("SS"); and (b) the slump-derived release of additional solutes (e.g., nutrients) by mixing slump POC with filtered downstream water (“SD”).

\subsubsection{Experiment: Variability as a function of transport potential}

85 SE within-slump runoff was split into three sieve size fractions $(63-2000 \mu \mathrm{m}, 20-63 \mu \mathrm{m},<20 \mu \mathrm{m})$ by sieving a $0.5 \mathrm{~mL}$ aliquot and adding the resultant size fractions to filtered downstream water in $60 \mathrm{~mL}$ glass BOD bottles (supplementary S2, Fig. S6). An unfractionated control ( $0.5 \mathrm{~mL}$ in $60 \mathrm{~mL}$ downstream water) was also created, and bottles were incubated for 8 days in the dark at ca. $20^{\circ} \mathrm{C}$ as above. Since relative concentrations of each size fraction were maintained, the $<20 \mu \mathrm{m}$ fraction had orders of magnitude greater total suspended solid (TSS) concentrations than the larger two (Table S2). We also incubated

90 filtered and unfiltered (but diluted, Table S2) stream water from upstream, downstream, and $2.79 \mathrm{~km}$ downstream of SE to accompany size fraction incubations. We characterized OC differences between size fractions using: (a) 14C age, (b) percent OC (i.e., OC: TSS), and (c) absorbance and fluorescence spectra of based-extracted particulate organic matter (BEPOM) (Osburn et al., 2012)(supplementary S3).

\subsubsection{Measurements}

95 We measured: (a) concentrations of DOC, POC, and TOC, and SUVA 254 (an optical proxy for dissolved organic matter (DOM) aromaticity) (Weishaar et al., 2003) at the beginning and end of incubations; and (b) $\mathrm{O}_{2}$ concentrations $\sim$ daily (PreSens, Fibox4, SP-PSt3-NAU-D5-YOP) to provide insight on rate of change (Richardson et al. 2013). We assumed heterotrophic breakdown of $\mathrm{OC}$ would be the dominant $\mathrm{O}_{2}$ consumption pathway, as respiratory quotients across several freshwater sites have been noted to vary around 1 (Berggren et al., 2012). Incubation $\mathrm{O}_{2}$ concentrations presented never dropped below $2 \mathrm{mg} \mathrm{L}^{-1}$; a threshold well above $\mathrm{O}_{2}$ limiting concentrations for different bacterial species (Stolper et al., 2010 and references therein). One exception was one of four replicates for the SE unfractionated treatment, which was removed and replaced with the mean of replicates for statistics. Our experiments aimed to mimic conditions downstream, thus slump-affected incubations had POC concentrations ranging from 1.4 to 18.6 times DOC concentrations. Samples for TSS concentration were collected alongside POC. Further details in supplementary S3. 
https://doi.org/10.5194/bg-2021-150

Preprint. Discussion started: 2 July 2021

(c) Author(s) 2021. CC BY 4.0 License.

(c) (i)

105

\subsubsection{Follow-up experiments}

First, to assess processes that may have contributed to $\mathrm{O}_{2}$ loss coupled with OC gains observed in 2015 and 2016, we undertook two follow up experiments. First, we combined $0.15 \mathrm{mg}$ of sterilized HD debris tongue sediments (collected in 2016)(Zolkos and Tank, 2020) with $18.2 \Omega$ Milli-Q (MQ) water to assess abiotic $\mathrm{O}_{2}$ loss. We incubated $60 \mathrm{~mL}$ glass BOD bottles on a shaker table in the dark at ca. $20^{\circ} \mathrm{C}$ for 7 days, monitoring $\mathrm{O}_{2}$ as above. Second, we measured change in dissolved and particulate inorganic carbon (DIC, PIC), in addition to change in DOC and POC, in an incubation combining FM3 slump runoff with downstream water, including sterilized replicates. The treatments were designed to replicate treatment "SD" in 2015. Sterilization was achieved by autoclaving and adding $\mathrm{ZnCl}_{2}$ as a poison and was validated using plate counts (supplementary S4). We hypothesized chemosynthesis associated with nitrification and sulfide oxidation (eqns. 2-4) could generate OC and so we additionally measured dissolved inorganic nitrogen $\left(\mathrm{NH}_{4}{ }^{+}, \mathrm{NO}_{3}{ }^{-}, \mathrm{NO}_{2}{ }^{-}\right)$and sulfate $\left(\mathrm{SO}_{4}{ }^{2-}\right)$. Sediments in sterilized and unsterilized bottles were characterized using X-ray diffraction (XRD) (supplementary S3.4).

$\mathrm{NH}_{3}+1.5 \mathrm{O}_{2} \leftrightarrow \mathrm{NO}_{2}^{-}+\mathrm{H}^{+}+\mathrm{H}_{2} \mathrm{O}$

$\mathrm{NO}_{2}^{-}+0.5 \mathrm{O}_{2} \leftrightarrow \mathrm{NO}_{3}^{-}$

120

$\mathrm{CO}_{2}+\mathrm{H}_{2} \mathrm{~S}+\mathrm{O}_{2}+\mathrm{H}_{2} \mathrm{O} \leftrightarrow\left[\mathrm{CH}_{2} \mathrm{O}\right]+\mathrm{H}_{2} \mathrm{SO}_{4}$

$\mathrm{FeS}_{2}+3.75 \mathrm{O}_{2}+3.5 \mathrm{H}_{2} \mathrm{O} \leftrightarrow+2 \mathrm{H}_{2} \mathrm{SO}_{4}+\mathrm{Fe}(\mathrm{OH})_{3}$

$\mathrm{H}_{2} \mathrm{SO}_{4}+2(\mathrm{Ca}, \mathrm{Mg}) \mathrm{CO}_{3} \leftrightarrow 2\left(\mathrm{Ca}^{2+}, \mathrm{Mg}^{2+}\right)+\mathrm{SO}_{4}^{2-}+2 \mathrm{HCO}_{3}^{-}$

125 Note that equation 2 is a general equation of chemolithoautotrophic reduced sulfur oxidation that can have a variable stoichiometry and assumes sulfur oxidizing bacteria exclusively produce $\mathrm{SO}_{4}{ }^{2-}$, rather than both $\mathrm{SO}_{4}{ }^{2-}$ and $\mathrm{S}^{0}$ ((Klatt and Polerecky, 2015; Nelson et al., 1986). Equation 3 shows a net reaction for a model of pyrite oxidation at circumneutral-pH (Percak-Dennett et al., 2017). This sulfide oxidation can generate sulfuric acid that can weather carbonates (e.g., eq. 4) or silicates (Zolkos and Tank, 2020; Zolkos et al., 2020).

\subsection{Data analyses}

Two-way ANOVAs, with site and treatment as fixed effects, were used to assess the effect of POC presence (UF vs SU), source (UU vs SU), dissolved matrix (SU vs SD), and settling (SU vs SS) on percent changes in OC (DOC, POC, and TOC), DOM aromaticity $\left(\mathrm{SUVA}_{254}\right)$ and $\mathrm{O}_{2}$ loss rate. One-way ANOVAs were also used to assess differences in the aforementioned changes between size fractions (2016 experiment). Two-way ANOVAs were used to assess the effect of distance and filtration

135 (fixed effects) for the 2016 transect experiments. Significant interactions/main effects were followed up with Tukey-adjusted pair-wise t-tests (Zar, 2010). We also calculated 95\% confidence intervals to evaluate whether OC changes significantly 
https://doi.org/10.5194/bg-2021-150

Preprint. Discussion started: 2 July 2021

(c) Author(s) 2021. CC BY 4.0 License.

(c) (i)

Discussions

differed from zero. Principal components analyses were used to visualize differences in optical indices between size fractions (2016), and changes in DOM and BEPOM (2019). To assess factors controlling in situ CO2 and O2 dynamics we calculated departures of $\mathrm{O}_{2}$ and $\mathrm{CO}_{2}$ from atmospheric equilibrium (Vachon et al. 2019) using 2015 in situ measurements of dissolved

$140 \mathrm{O}_{2}$ at several slump sites (Shakil et al., 2020) and coupled $\mathrm{CO}_{2}$ departures (Zolkos et al., 2019). For further details, see Appendix A. Data for this publication is available through Shakil et al. (2021).

\section{Results}

\subsection{Experiment 2015: Effects of POC presence and source}

Across experiments, declines in POC were not observed, and in some cases, POC increased (Fig. 2). Slump runoff addition

145 into filtered upstream water (SU) did not significantly alter $\% \Delta \mathrm{DOC}, \triangle \mathrm{SUVA} 254$ (change in DOM aromaticity), or $\% \Delta \mathrm{TOC}$ (p>0.05; Table A1, Fig. 2) relative to the upstream filtered control (UF). Similarly, POC source (slump [SU] vs. unfiltered upstream [UU]) did not significantly affect $\% \Delta$ TOC or $\triangle$ SUVA254 (p>0.05, Table A1, Fig. 2). However, $\% \Delta$ POC were significantly lower when particles were sourced from slump runoff (UU vs. SU; $p<0.001$, Table A1), potentially because particle concentrations were orders of magnitude lower in upstream bottles (Table S2). DOC increased in the presence of 150 upstream particles (UU) but decreased in the presence of slump particles (SU), though this difference was marginally insignificant (Table A1, $\mathrm{p}=0.053$ ). Despite no effect on \% $\%$ TOC (Table A1), the addition of slump particles (SU) did significantly increase rates of $\mathrm{O}_{2}$ consumption compared to upstream filtered and unfiltered treatments (UF and UU; Fig. 2 AC), though this effect was dependent on slump site (significant interactions, Table A1; note lack of increase for site HD where slump runoff encroached upstream site). 
Table 1. Summary of experiments and main results with reference to figures and text sections for details.

\begin{tabular}{|c|c|c|c|c|c|c|c|}
\hline $\begin{array}{l}\text { Yea } \\
\mathrm{r}\end{array}$ & $\begin{array}{l}\text { Field } \\
\text { Samplin } \\
\mathrm{g}\end{array}$ & $\begin{array}{l}\text { Exp. } \\
\text { Detail } \\
\mathrm{s}\end{array}$ & $\begin{array}{c}\text { \#day } \\
\mathrm{s}\end{array}$ & Test & Treatments & Main result & Considerations \\
\hline \multirow[t]{4}{*}{$\begin{array}{l}201 \\
5\end{array}$} & \multirow{4}{*}{$\begin{array}{l}\text { UP, IN, } \\
\text { and DN } \\
\text { of } \\
\text { slumps } \\
\text { HA, } \\
\text { HB, HD }\end{array}$} & \multirow[t]{4}{*}{$\begin{array}{l}\text { Sec. } \\
2.2 .1 \\
\text { Fig. } \\
\text { S5 }\end{array}$} & \multirow[t]{4}{*}{7} & $\begin{array}{l}\text { POC } \\
\text { presence }\end{array}$ & $\begin{array}{l}\text { SU ( slump in } \\
\text { filtered upstream) } \\
\text { vs. UF (filtered } \\
\text { upstream) }\end{array}$ & \multirow{2}{*}{$\begin{array}{l}\text { (1) between treatments: no } \\
\text { effect on } \% \Delta \text { TOC but } \\
\text { increased } \mathrm{O}_{2} \text { loss; (2) within } \\
\text { treatments: no sig. TOC loss } \\
\text { (Fig 2, Table Al) }\end{array}$} & \\
\hline & & & & $\begin{array}{l}\text { POC } \\
\text { source }\end{array}$ & $\begin{array}{l}\text { SU vs. UU } \\
\text { (unfiltered } \\
\text { upstream) }\end{array}$ & & \\
\hline & & & & $\begin{array}{l}\text { Dissolved } \\
\text { constitue } \\
\text { nts }\end{array}$ & $\begin{array}{l}\text { SU vs. SD (slump } \\
\text { in filtered } \\
\text { downstream) }\end{array}$ & $\begin{array}{l}\text { (1) Between treatments: no } \\
\text { effect on } \% \Delta \text { TOC or } \mathrm{O}_{2} \text { loss; } \\
\text { (2) within treatments: no sig. } \\
\text { TOC loss } \\
\text { (Fig 2, Table Al) }\end{array}$ & \\
\hline & & & & Settling & $\begin{array}{l}\text { SU vs. SS (SS off } \\
\text { rotator to allow } \\
\text { settling) }\end{array}$ & $\begin{array}{l}\text { (1) Between treatments: no } \\
\text { effect on } \% \Delta \text { TOC, reduced } \\
\mathrm{O}_{2} \text { loss; (2) within } \\
\text { treatments: no sig. TOC loss } \\
\text { (Fig 2, Table A1) }\end{array}$ & \\
\hline \multirow[t]{2}{*}{$\begin{array}{l}201 \\
6\end{array}$} & \multirow[t]{2}{*}{$\begin{array}{l}\text { UP, IN, } \\
\text { DN, } \\
\text { and } \\
2.79 \mathrm{~km} \\
\text { DN of } \\
\text { slump } \\
\text { SE }\end{array}$} & \multirow[t]{2}{*}{$\begin{array}{l}\text { Sec. } \\
2.2 .2 \\
\text { Fig. } \\
\text { S6 }\end{array}$} & \multirow[t]{2}{*}{8} & $\begin{array}{l}\text { Biodegra } \\
\text { dability } \\
\text { vs. } \\
\text { transport } \\
\text { potential }\end{array}$ & $\begin{array}{l}\text { Sieve size } \\
\text { fractions: } \\
\text { (1) } 2000-63 \mu \mathrm{m} \\
\text { (2) } 63-20 \mu \mathrm{m} \\
\text { (3) }<20 \mu \mathrm{m}) \text {. } \\
\text { + unfractionated } \\
\text { reference }\end{array}$ & $\begin{array}{l}\text { No sig. diff. in } \% \Delta \text { TOC or } \\
\% \Delta \text { POC changes between } \\
\text { size fractions but sig. TOC } \\
\text { gain and largest DOC loss } \\
\text { for particles }<20 \mu \mathrm{m} \\
\text { (Fig 2, Table A2) }\end{array}$ & $\begin{array}{l}\downarrow[\mathrm{TSS}] \text { in two larger } \\
\text { size fractions relative } \\
\text { to smallest, two } \\
\text { largest also within } \\
\text { MQ error }\end{array}$ \\
\hline & & & & $\begin{array}{l}\text { Transect } \\
\text { validation }\end{array}$ & $\begin{array}{l}\text { unfiltered and } \\
\text { filtered DN vs. } \\
2.79 \mathrm{~km} \mathrm{DN.} \mathrm{+} \\
\text { UP reference }\end{array}$ & $\begin{array}{l}\text { Change in downstream } \\
\text { distance: no effect on } \\
\% \Delta \text { TOC; within treatments: } \\
\text { no sig. TOC loss } \\
\text { (Fig 2, Table A3) }\end{array}$ & $\begin{array}{l}\text { UP and } 2.79 \mathrm{~km} \mathrm{DN} \\
\text { within MQ blank } \\
\text { error }\end{array}$ \\
\hline $\begin{array}{l}201 \\
8\end{array}$ & $\begin{array}{l}\text { HD } \\
\text { debris } \\
\text { tongue } \\
\text { material }\end{array}$ & $\begin{array}{l}\text { Sec. } \\
2.2 .4\end{array}$ & 7 & $\begin{array}{l}\text { Abiotic } \\
\mathrm{O}_{2} \text { loss }\end{array}$ & $\begin{array}{l}\text { Sterilized debris } \\
\text { tongue sediments } \\
\text { in Milli-Q (MQ) } \\
\text { water vs. MQ } \\
\text { control } \\
\end{array}$ & $\begin{array}{l}\text { Rapid } \mathrm{O}_{2} \text { loss in absence of } \\
\text { microbial activity } \\
\text { (Fig S3a) }\end{array}$ & $\begin{array}{l}\text { MQ may accelerate } \\
\text { weathering, HD } \\
\text { debris sediments an } \\
\text { extreme weathering } \\
\text { endmember }\end{array}$ \\
\hline $\begin{array}{l}201 \\
9\end{array}$ & $\begin{array}{l}\text { IN and } \\
\text { DN of } \\
\text { slump } \\
\text { SC }\end{array}$ & $\begin{array}{l}\text { Sec. } \\
2.2 .4 \text {, } \\
\text { Fig. } \\
\text { S7 }\end{array}$ & 27 & $\begin{array}{l}\text { paired } \\
\text { inorganic } \\
\text { carbon } \\
\text { changes } \\
\text { \& chemo- } \\
\text { lithotroph } \\
\text { y }\end{array}$ & $\begin{array}{l}\text { Unsterilized } \\
\text { mimic of SD } \\
\text { (2015 treatment) } \\
\text { vs. sterilized SD. } \\
\text { + MQ blanks }\end{array}$ & $\begin{array}{l}\text { Prior gains not replicated but } \\
\text { only } 4 \% \text { of TOC } \\
\text { mineralized, greater sulfate } \\
\text { gains and nitrification in } \\
\text { unsterilized treatments (Fig } \\
\text { 4) }\end{array}$ & $\begin{array}{l}\text { SC slump in a } \\
\text { different landscape } \\
\text { type than SE and HA } \\
\text { where prior gains } \\
\text { were observed, } \\
\text { sterilization } \\
\text { treatments may not } \\
\text { be a true abiotic } \\
\text { control }\end{array}$ \\
\hline
\end{tabular}



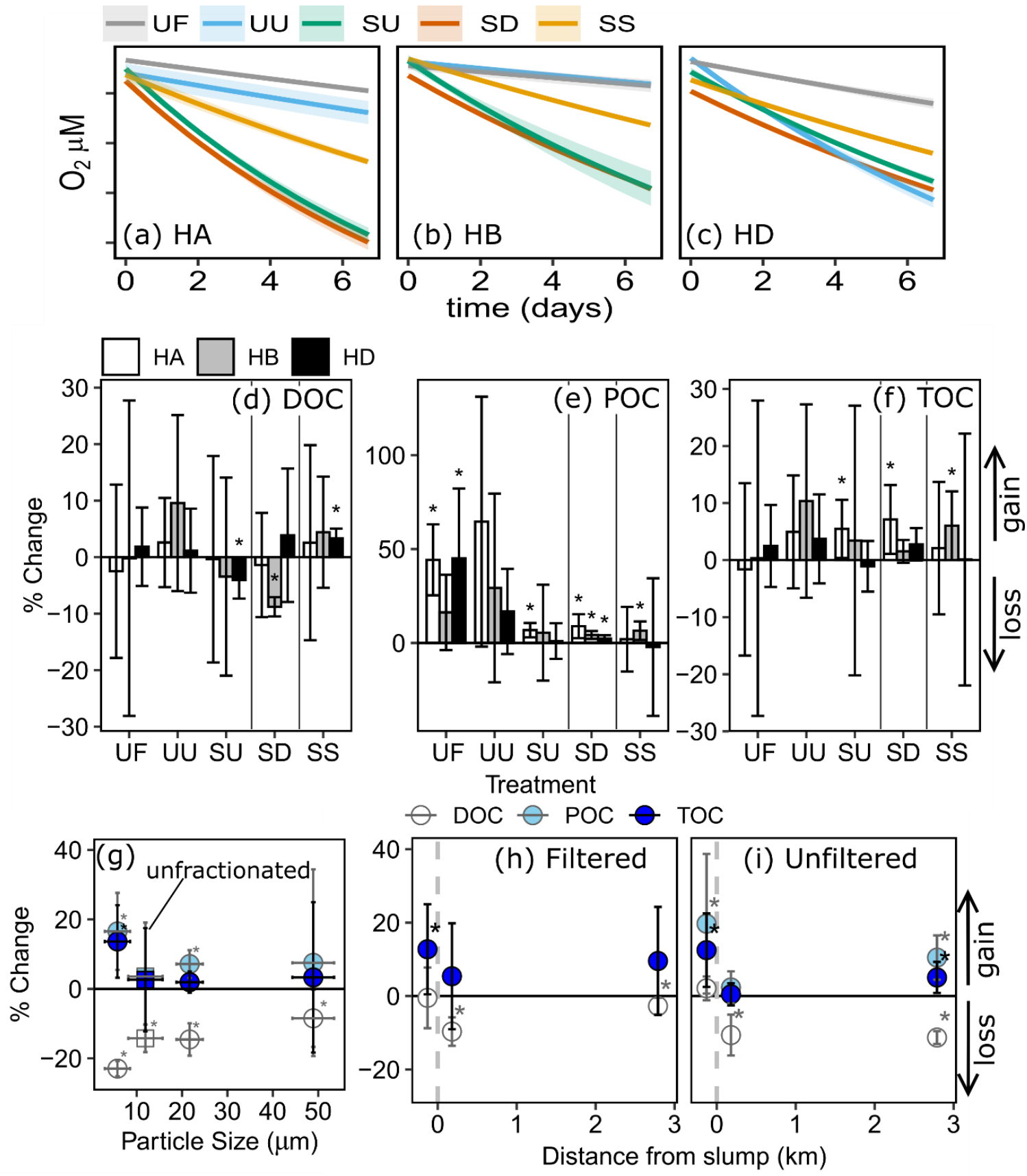

Figure 2: (a-c) Measured (point) and modelled (line) $\mathrm{O}_{2}\left(\mathrm{mg} \mathrm{L}^{-1}\right)$ across combinations of source material and settling effects. Percent change in DOC, POC, and TOC in comparison to: (d-f) combinations of source material and settling effects; (g) geometric mean particle size; and (h-i) distance from slump site. Vertical errors are $95 \%$ confidence intervals with asterisks marking significant differences from zero. Horizontal errors (e) are particle size geometric standard deviation. Codes (a-f): filtered (UF) and unfiltered (UU) upstream, slump material in upstream (SU) and downstream (SD) filtrate, and SU settled out (SS). HA, HB, and HD are slump sites. 
https://doi.org/10.5194/bg-2021-150

Preprint. Discussion started: 2 July 2021

(c) Author(s) 2021. CC BY 4.0 License.

(c) (i)

\subsection{Experiment 2015: Effects of background dissolved constituents and settling}

Changing filtrate to downstream water, which has higher ion and nutrient concentrations (Shakil et al. 2020), had no significant effect on any parameter measured in the experiment (SU vs. SD, Table A1). Allowing slump particles to settle (SU vs SS) did not affect $\% \triangle \mathrm{TOC}$ but did significantly reduce $\mathrm{O}_{2}$ consumption rates. Mean DOC concentrations also switched from decreasing to increasing (Fig. 2D, though the difference was not significant; $p=0.10$, Table A1).

\subsection{Experiment 2016: Variability dependent on transport potential}

Based on 14C age, \%POC, and relative contribution of fluorescent peak C (Coble, 2007), larger particle size fractions appeared to be associated with fresher terrestrial-origin organic matter than smaller size fractions (Appendix B). POC associated with particles $<20 \mu \mathrm{m}$ dated to $>27,000 \mathrm{cal} \mathrm{BP}$, while POC associated with particles ranging from $20-63 \mu \mathrm{m}$ and $63-2,000 \mu \mathrm{m}$ dated to $\sim 19,600$ cal BP and $\sim 8,000$ cal BP respectively (Table B1).

Only bottles containing particles $<20 \mu \mathrm{m}$ displayed significant gains in TOC (95\% CI; Fig. 2G-I) but we did not find a significant difference in $\% \triangle \mathrm{TOC}$ or $\% \triangle \mathrm{POC}$ between size fractions (ANOVA; Table A2). DOC losses occurred in all treatments downstream of slumps, to a greater degree when particles were present (i.e., unfiltered treatments) (Fig. 2H-I, $\mathrm{p}<0.05$ Table A3), and were significantly greater when particles were $<20 \mu \mathrm{m}$ ( $<<0.05$, Fig. 2G, Table A2). Increases in

180 SUVA254 were also significantly greater for $<20 \mu \mathrm{m}$ particle treatments ( $<<0.05$ Table A2 and $\mathrm{C} 1$ ), as were TSS concentrations (Table S2). \%DOC loss was also significantly greater $2.79 \mathrm{~km}$ downstream of SE compared to immediately downstream (Table A3).

\section{$3.4 \mathrm{O}_{2}$ vs. carbon}

Change in $\mathrm{O}_{2}$ and TOC generally did not follow the 1:1 trend expected if heterotrophic respiration dominated metabolic 185 processing (Fig. 3 A-C). The greatest deviations from 1:1 was observed in treatments containing slump runoff, where despite large losses in $\mathrm{O}_{2}$, we saw non-significant changes to gains in TOC. Increases in TOC from upstream, filtered, and $2.79 \mathrm{~km}$ downstream bottles were within the range of experimental blanks (Figure 3C).

The rate of $\mathrm{O}_{2}$ consumption within and across experiments was generally greater in treatments with greater initial TSS (Fig. 3D). However, there was no consistent relationship between TOC changes and initial TSS (Fig. 3E), but some of the greatest

190 TOC increases occurred during incubations of SE particles $<20 \mu \mathrm{m}$ and HA slump particles in upstream (SU) and downstream (SD) filtrate, treatments amongst those with the greatest initial TSS (Fig. 3A, B, E).

In-situ comparisons of $\mathrm{O}_{2}$ vs. $\mathrm{CO}_{2}$ showed within-slump samples to have the greatest excess $\mathrm{CO}_{2}$, with several samples substantially departing from the $1 \mathrm{CO}_{2}:-1 \mathrm{O}_{2}$ stoichiometry associated with heterotrophic respiration (Fig. 3F). In contrast, several downstream and upstream sites display measurements close to atmospheric equilibrium for $\mathrm{CO}_{2}$ but are supersaturated for $\mathrm{O}_{2}$, potentially due to temperature changes and lower solubility of $\mathrm{O}_{2}$ (Vachon et al., 2020). 
https://doi.org/10.5194/bg-2021-150

Preprint. Discussion started: 2 July 2021

(c) Author(s) 2021. CC BY 4.0 License.

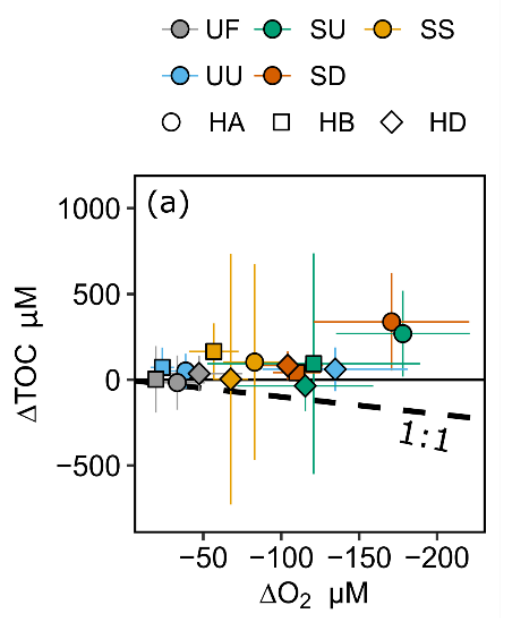
$\square \mathrm{MQ}$
$\diamond 63-20 \mu \mathrm{m}$
- Unfractionated $\Delta<20 \mu \mathrm{m}$
ㅁ $2000-63 \mu \mathrm{m}$

$\bigcirc \quad M Q \quad \circ \quad 0.18 \mathrm{~km} \mathrm{DN}$

$\bigcirc$ UP $\bigcirc 2.79 \mathrm{~km} D N$
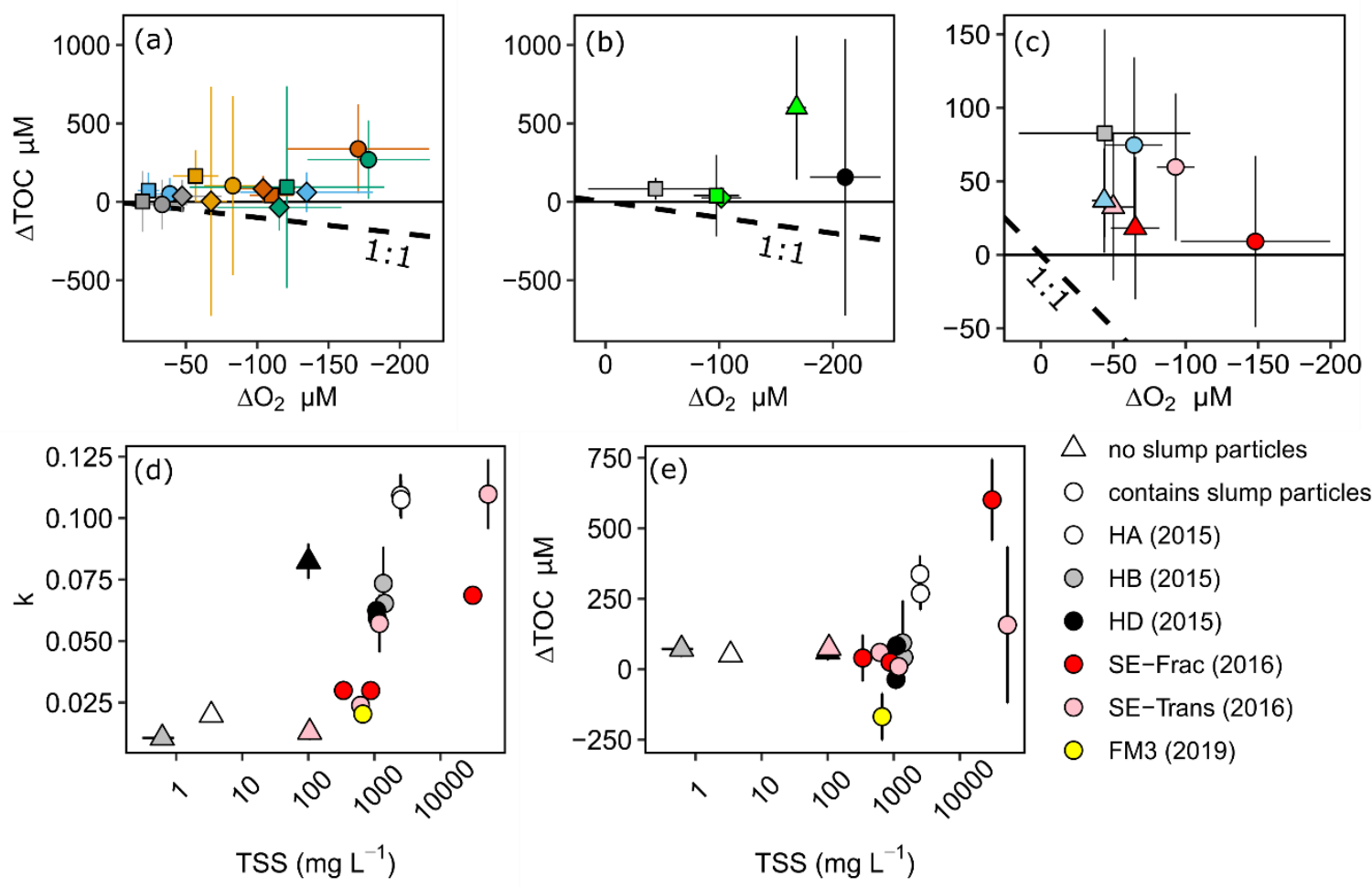

$\triangle$ no slump particles

contains slump particles

O HA (2015)

O HB (2015)

- HD (2015)

- SE-Frac (2016)

O SE-Trans (2016)

O FM3 (2019)

TSS ( $\left.\mathrm{mg} \mathrm{L}^{-1}\right)$

TSS $\left(\mathrm{mg} \mathrm{L}^{-1}\right)$

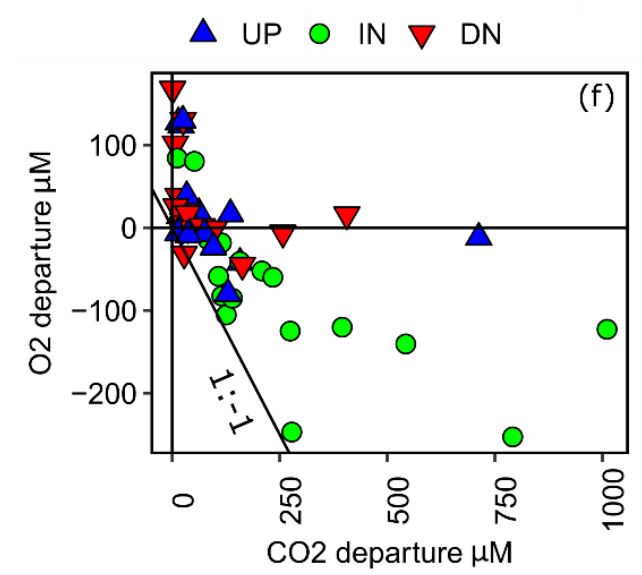

Figure 3: Changes in TOC vs. changes in dissolved $\mathrm{O}_{2}$ for: (a) test of biodegradability; (b) site SE fractionation experiment; and (c) site SE transect experiment. Dashed lines in a-c represent predicted loss of $\mathrm{OC}$ for respiratory quotient=1 and error bars show $95 \%$ confidence intervals. (d-e) Exponential rate of $\mathrm{O}_{2}$ consumption $(\mathrm{k})$ or changes in TOC vs. initial TSS for treatments across experiments, excluding filtered, settled, and sterilized treatments from a-c. SE-Frac indicates the fractionated treatments from panel (b). (f) Departures of $\mathrm{O}_{2}$ and $\mathrm{CO}_{2}$ from atmospheric equilibrium in samples collected upstream (UP), downstream (DN) and within (IN) a series of slump sites on the Peel Plateau. Error bars in (d) and (e) show standard error of the mean. Codes in (a): filtered (UF) and unfiltered (UU) upstream, slump material in upstream (SU) and downstream (SD) filtrate, and SU settled out (SS). HA, HB, and HD are slump sites. 
https://doi.org/10.5194/bg-2021-150

Preprint. Discussion started: 2 July 2021

(c) Author(s) 2021. CC BY 4.0 License.

(c) (i)

\subsection{Follow-up experiments}

\subsubsection{8 test: sterilized debris sediments in Milli-Q water}

Oxygen was completely consumed $(\sim 226 \mu \mathrm{M})$ in bottles containing sterilized HD debris tongue material suspended in Milli-

210 Q water within 4-5 days, exceeding the $\mathrm{O}_{2}$ loss rates previously observed (Table S1, Fig. S3a). Bottles containing sterilized sediments had lower $\mathrm{pH}(5.52-6.09)$ following incubation than MQ controls $(6.53-6.91)$.

\subsubsection{9 test: inorganic carbon changes and potential chemolithotrophy}

Oxygen consumption occurred in sterilized treatments $(-15 \pm 6 \mu \mathrm{M}$, mean $\pm 95 \% \mathrm{CI}, \mathrm{t}=27$ days) but was more pronounced in unsterilized bottles $(-124 \pm 15 \mu \mathrm{M})$. The pronounced $\mathrm{O}_{2}$ decline in unsterilized bottles was accompanied by a significant

215 loss of DOC $(-83 \pm 26 \mu \mathrm{M})$ and a non-significant loss of POC $(-85 \pm 261 \mu \mathrm{M})$, balancing to a non-significant loss of TOC ($170 \pm 262 \mu \mathrm{M}$, Fig. 4). Total inorganic carbon (TIC) increased significantly in unsterilized treatments, driven by increases in DIC. In sterilized bottles, modest oxygen losses were accompanied by significant DOC losses $(-93 \pm 51 \mu \mathrm{M})$, significant POC gains $(141 \pm 33 \mu \mathrm{M})$, balancing to a modest non-significant gain in TOC $(48 \pm 66 \mu \mathrm{M})$. TIC had a minor significant decrease $(-25 \pm 20 \mu \mathrm{M})$, driven by losses in DIC.

220 Ammonium decreased from $8.68 \pm 0.47 \mu \mathrm{M}$ to below detection $(0.2 \mu \mathrm{M})$ in unsterilized bottles, while nitrite and nitrate increased by $2.58 \pm 2.36$ and $1.33 \pm 1.67 \mu \mathrm{M}$, respectively. In sterilized bottles, ammonia increased by $6.74 \pm 1.80 \mu \mathrm{M}$ alongside negligible changes in nitrate or nitrite. Sulfate generation was greater in unsterilized $(90 \pm 6 \mu \mathrm{M})$ than sterilized (54 $\pm 23 \mu \mathrm{M}$ ) bottles, but for both treatments sulfate increased more than would be expected via pyrite oxidation (Fig. 4D, based on oxygen stoichiometry in eq. S3). However, the only sulfur-bearing mineral detected in sediments (XRD; $1-5 \%$ detection 225 limit, this study) was pyrite.

A biplot of PCA components 1 and 2 did not reveal any shifts in BEPOM or DOM optical characteristics during incubation of unsterilized treatments (Fig. 4D-E). However, DOM from sterilized treatments shifted towards lower molecular weight (SR, slope ratio), lower aromatic material $\left(\mathrm{SUVA}_{254}\right)$ of greater biological origin (BIX). PC1 separated DOM in sterilized and unsterilized bottles, suggesting sterilization processes increased the proportion of simple compounds which cautions against assuming the sterilized treatment is a true abiotic control of organic matter changes. 


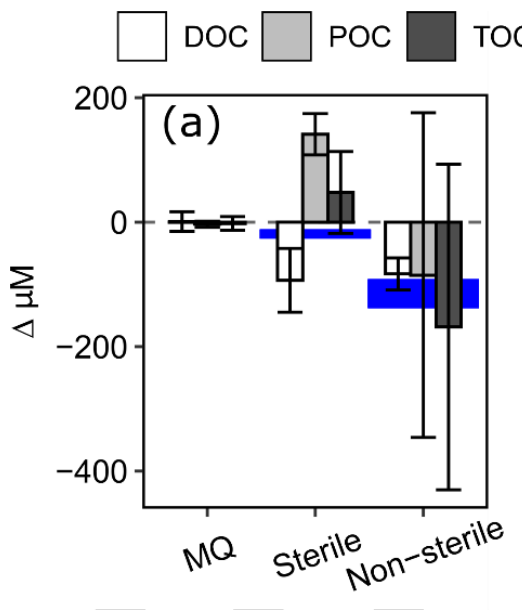

TOC $\square$ DIC $\square$ PIC $\square$ TIC
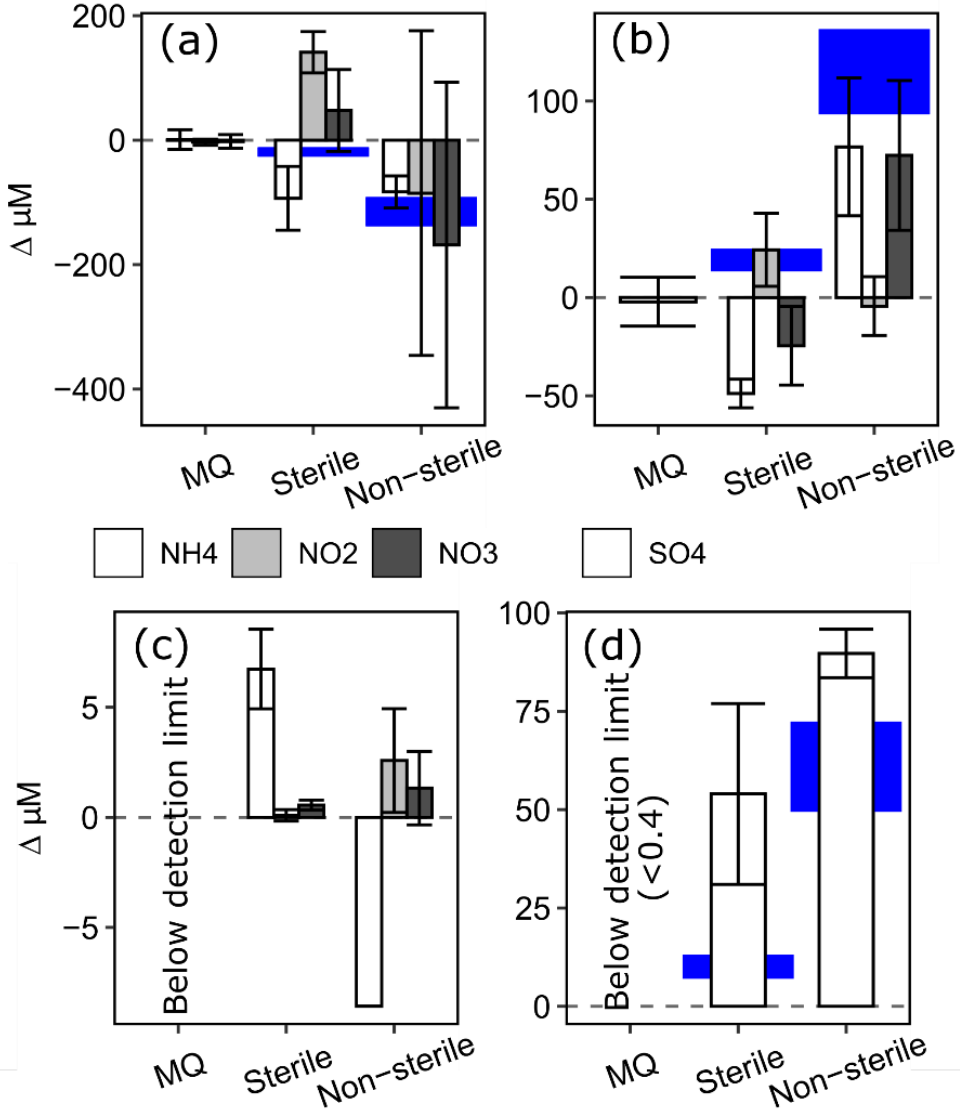

3

$\mathrm{SO} 4$

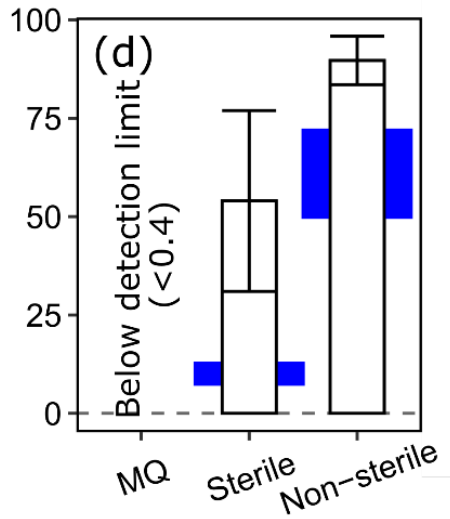

Sterile $\Delta$ Non-sterile
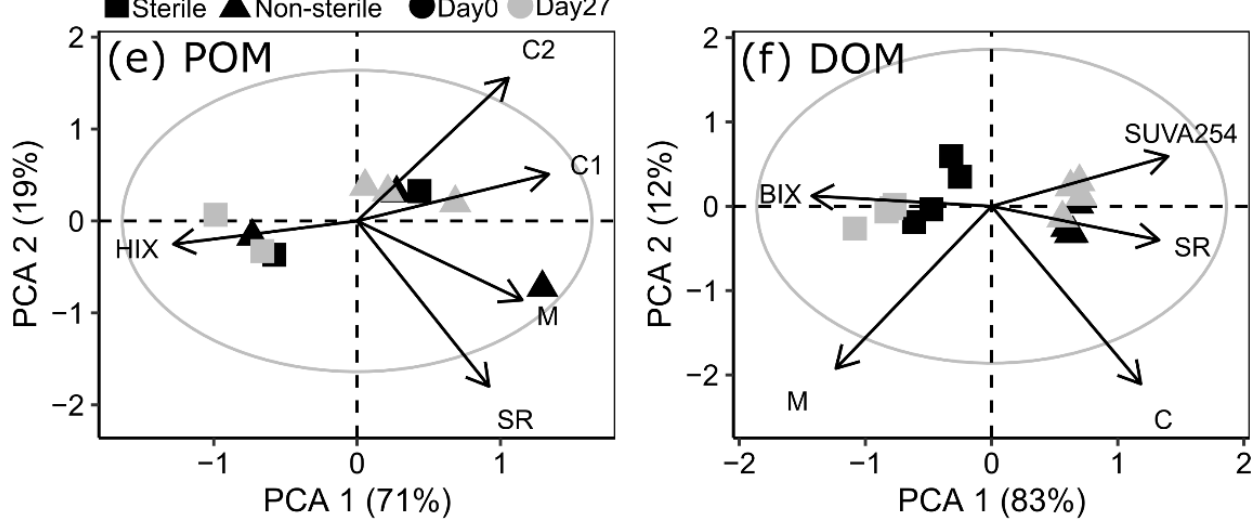

Figure 4: Changes in millimolar concentrations of: (a) organic carbon; (b) inorganic carbon; (c) ammonium $\left(\mathrm{NH}_{4}^{+}\right)$, nitrite $\left(\mathrm{NO}_{2}{ }^{-}\right)$, and nitrate $\left(\mathrm{NO}_{3}{ }^{-}\right)$; and $(\mathrm{d})$ sulfate $\left(\mathrm{SO}_{4}{ }^{2-}\right)$ in 2019 test of interferences. Note difference in scales between panels. Blue shades highlight potential carbon gains or losses based on $\mathrm{O}_{2}$ loss and a respiratory quotient of $1(\mathrm{a}-\mathrm{b})$ and potential sulfate generated from pyrite oxidation (eq. 3). Error bars and blue heights both show a range representing 95\% confidence intervals. (e-f) PCA biplot of components 1 and 2 showing variation in POM (e) and DOM (f) optics. Grey circle outlines circle of equilibrium contribution, plot shown in scaling 1. 
https://doi.org/10.5194/bg-2021-150

Preprint. Discussion started: 2 July 2021

(c) Author(s) 2021. CC BY 4.0 License.

\section{Discussion}

Our incubations, coupled with multiple studies examining slump-POC composition (Shakil et al., 2020; Bröder et al., 2021; Keskitalo et al., 2021) indicate that slump-mobilized POC in glacial landscapes of western Canada has low biodegradability on the Peel Plateau. We found no significant losses of POC or TOC or evidence that $\% \triangle T O C$ increased in streams due to slump-mobilized POC across slump sites and for varying size fractions and distances downstream of slump SE. While $\% \Delta$ TOC did not significantly differ across size fractions of slump SE particles, particles most likely to remain in transport $(<20 \mu \mathrm{m})$ enabled the greatest loss in $\% \triangle \mathrm{DOC}$ (linked to greater TSS) and significant gains in TOC. A coupled transect experiment showed that downstream of SE, TOC gains were not significant or were within error of blanks ( $2.79 \mathrm{~km}$ downstream), though both downstream treatments had orders of magnitude lower TSS than the $<20 \mu \mathrm{m}$ size fraction treatment sourced directly from slump runoff.

The lack of biodegradability contrasted elevated $\mathrm{O}_{2}$ consumption rates downstream of slumps, except for slump HD, where slump runoff encroached into the upstream site (Fig. S4). OC gains suggest potential for chemoautotrophic carbon sequestration. Further, abiotic processes (e.g., mineral oxidation) appear to have the potential to consume oxygen rapidly enough to decouple oxygen and carbon dynamics from the 1:1 relationship associated with heterotrophic respiration, as suggested by sterile incubations of $\mathrm{HD}$ debris material. The excess in situ $\mathrm{CO}_{2}$ concentrations we observe are likely from mineral weathering that can generate $\mathrm{CO}_{2}$ in this system (Zolkos et al., 2018).

Our finding of low POC biodegradability is likely conservative since incubations focus on the most labile period (7-27 days) (Richardson et al., 2013). Our longest incubation (27 d; Fig. 4 non-sterile) did not show significant TOC losses, though 95\% error spanning losses expected from a 1:1 relationship with $\mathrm{O}_{2}$ suggests that detection of change may be masked by error in POC measurements (Fig. 4a). Using $\triangle \mathrm{TIC}$ as an alternate metric of carbon mineralization, we estimate that $\sim 4 \%$ of the initial TOC pool may have been mineralized within $27 \mathrm{~d}$. Time series experiments on TOC degradation from similarly glaciallyconditioned Qikiqtaruk (Herschel Island) indicate that $\mathrm{CO}_{2}$ production ceased by the end of a 120-day incubation, and greater than half $(\sim 58 \%)$ of total $\mathrm{CO}_{2}$ was produced within the first $27 \mathrm{~d}$. Assuming a similar pattern for OC mineralization, we estimate $\sim 7 \%$ of slump-mobilized TOC on the Peel Plateau may be readily mineralized during transport in streams. These findings are consistent with measures of little change in $\mathrm{CO}_{2}$ concentrations downstream relative to upstream of slumps (Zolkos et al., 2019), despite orders of magnitude increases in POC and TOC (Shakil et al., 2020). We note that rapid within-slump processing of labile components prior to entrainment within streams may still occur, as supported by high $\mathrm{NH}_{4}{ }^{+}$concentrations (Shakil et al., 2020) indicative of decomposition (Tanski et al., 2017), low representation of labile compounds in the slump scar zone and stream sediments relative to headwall sources (active layer)(Keskitalo et al., 2021), and excess $\mathrm{CO}_{2}$ in slump runoff resulting from both heterotrophic respiration and geogenic production (Zolkos et al., 2019)(Fig. 3F). OC rapidly lost 
https://doi.org/10.5194/bg-2021-150

Preprint. Discussion started: 2 July 2021

(c) Author(s) 2021. CC BY 4.0 License.

within-slump likely predominantly originates from the active layer (Bröder et al., 2021) and Holocene-age permafrost in areas where organic material buried in colluvial deposits from past slumping has preserved organics (Lacelle et al., 2019).

In addition to serving as a possible marker for decomposition, high concentrations of ammonia may stimulate nitrification and associated chemosynthetic carbon sequestration. Though we did not see significant TOC gains in our 2019 experiment, ammonia loss coupled with nitrite production suggests active nitrification. Nitrifying bacteria have slow growth rates (Sinha and Annachhatre, 2007; Bock and Wagner, 2013), with the molar ratio of $\mathrm{NH}_{4}{ }^{+}$consumed to carbon fixed ranging from 25 100 (Ward 2013). Using this stoichiometry and initial ammonia concentrations estimated across 2015-16 incubations (Table S4) indicates that nitrification would be unlikely to fix more than $1 \mu$ mol L-1, in comparison to OC gains $601 \pm 459 \mu \mathrm{M}$ (mean $\pm 95 \%$ CI of SE $<20 \mu \mathrm{m}$ incubation, Fig, 3B, Table S4). Chemolithoautotrophy by sulfur oxidizing bacteria can also sequester carbon (Klatt and Polerecky, 2015), with the ratio of $\mathrm{CO}_{2}$ sequestered to $\mathrm{O}_{2}$ consumed ranging from $0.09-0.41$ for aerobic thiosulfate oxidizers (Klatt and Polerecky, 2015). Given the high sediment concentration in streams affected by slumping (can exceed $800 \mathrm{~g} \mathrm{~L}-1$, Shakil et al. 2020), and the prevalence of sulfide minerals and oxidation across the Peel Plateau (Zolkos et al., 2018), chemolithoautotrophy associated with sulfide oxidation is a mechanism worth exploring as a counterbalance to OC mineralization. Precise techniques such as isotope labelling (Spona-Friedl et al., 2020) and the tracking of genes associated with carbon fixation processes (Percak-Dennett et al., 2017) may circumvent challenges associated with POC measurement errors and tracking multiple processes acting on $\mathrm{OC}$ end-point measurements.

This study and Tanski et al. (2019) both suggest DOC contributes more to heterotrophic $\mathrm{CO}_{2}$ production than POC in glacial margin landscapes. This seemingly contrasts protection of DOM by adsorption (Littlefair et al., 2017), however adsorption onto minerals tends to favour humic-like, oxygen-rich compounds, typically considered recalcitrant, over protein-like compounds (Groeneveld et al., 2020). Thus, sorption could "sort" labile carbon into the dissolved phase and relegate intrinsically recalcitrant ("humic-like", aromatic) carbon to mineral protection as POC. Evidence of this includes elevated lability of slump-mobilized DOM relative to upstream DOM (Littlefair et al., 2017; Littlefair and Tank, 2018), low lability of slump POM (Shakil et al., 2020; this study) and striking compositional similarity of DOC from slump-impacted streams on the Peel Plateau relative to other circumpolar regions with mineral soils (e.g., Yedoma regions)(Wologo et al., 2021). Where RTS sediments continue to sequester aromatic DOM during fluvial transport, the relative increase in lability in the remaining DOM pool may promote microbial OC oxidation and $\mathrm{CO}_{2}$ production downstream. However, when particles settle out, anoxia could result in release of adsorbed DOC to the overlying water column (Peter et al., 2016), which may explain the switch from mean DOC decreases to DOC increase in comparisons between rotated and settled slump treatments in 2015. Sorption appeared to occur in 2019 sterilized bottles as DOC concentrations declined but POC increased, and DOM aromaticity and molecular weight decreased. No change in DOM in unsterilized bottles may reflect sorption (loss of aromaticity) and degradation (gain 300 of aromaticity) acting simultaneously, which underlines challenges in quantifying process by measuring OC changes in bulk incubations and why DOC declines were not consistently followed by increases or decreases in $\mathrm{SUVA}_{254}$ across experiments, even when losses were consistent as in 2016. 
https://doi.org/10.5194/bg-2021-150

Preprint. Discussion started: 2 July 2021

(c) Author(s) 2021. CC BY 4.0 License.

\section{Conclusion}

Permafrost thaw slumping is increasing permafrost OC concentrations in streams across the Peel Plateau (Canada) by orders of magnitude, almost entirely in the form of POC (Kokelj et al., 2020; Shakil et al., 2020; Keskitalo et al., 2021). We find slump-POC has low biodegradability in streams, with $>90 \%$ likely to be sequestered in sediments after mobilization to streams. Increased input of minerals into streams creates potential for significant abiotic (sorption, mineral protection) and biotic (chemolithotrophy) sequestration effects. Targeted investigations of these multiple processes acting simultaneously on carbon dynamics require specific quantification in landscapes experiencing rapid change.

\section{Appendices}

\section{Appendix A: Data analysis details and ANOVA results}

The percent change of OC was used to measure differences in biodegradability:

$\% \triangle O C=\frac{\left(O C_{T n}-O C_{T O a v e r a g e}\right)}{O C_{\text {TOaverage }}}$

315 In eq. 1 above, $O C_{T_{n}}$ is the DOC, POC, or TOC measured at an end time point, and $O C_{\text {Toaverage }}$ is the mean OC measured at the beginning of the experiment. Since multiple outcomes were tested for ANOVAs, p-values of main tests were corrected for false discovery rate using padjust() from R package "emmeans" (Lenth, 2021). For 2015, main tests were corrected for 19 tests since SU treatments was tested in 4 comparisons and 3-4 outcomes were tested per comparison. For 2016, main tests were corrected for 4-5 tests since 4-5 outcomes were tested per ANOVA. Follow-up Tukey or Games-Howell adjusted pairwise ttests were conducted only when an interaction or main test of interest was significant. Prior to PCA we (a) used Pearson correlations to remove variables such that no variables within the PCA had a Pearson correlation greater than 0.9; (b) logtransformed all variables to prevent skew and (c) conducted a detrended correspondence analysis to ensure linearity of the dataset.

325 Table A1: Two-way ANOVAs of tests of sources, filtrate, and settling on biodegradability of POC in 2015 experiments. Follow-up tukey-adjusted pair-wise t-tests are shown where significant interactions were present. Since SU treatments were tested 3 times and multiple outcomes were tested, p-values reported in two-way ANOVAs were corrected for false discovery rate (FDR) (19 tests). Degrees of freedom associated with treatment, site, interaction, and residuals are 1, 2,

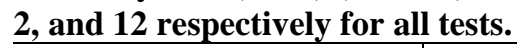

\begin{tabular}{|c|c|c|c|c|c|c|c|c|c|}
\hline \\
\hline \multicolumn{2}{|l|}{ Effect } & \multicolumn{4}{|l|}{ Treatment } & \multicolumn{2}{|l|}{ Site } & \multicolumn{2}{|c|}{ Treatment*Site } \\
\hline Test & Variable & estimate & error & $\mathrm{F} / \mathrm{t}^{\mathrm{a}}$ & $\mathrm{p}$ & $\mathrm{F}$ & $p$ & $\mathrm{~F}$ & $\mathrm{p}$ \\
\hline Control & $\triangle S U V A_{254}$ & - & - & 1.45 & 0.48 & 1.64 & 0.37 & 1.42 & 0.66 \\
\hline (SU-UF) & $\% \triangle \mathrm{DOC}$ & - & - & 0.54 & 0.75 & 0.02 & 0.98 & 0.54 & 0.81 \\
\hline & $\% \triangle T O C$ & - & - & 0.49 & 0.75 & 0.07 & 0.98 & 0.98 & 0.80 \\
\hline & $\ln (k)$ & - & - & 305.57 & 0.00 & 6.43 & 0.04 & 8.92 & 0.04 \\
\hline
\end{tabular}


https://doi.org/10.5194/bg-2021-150

Preprint. Discussion started: 2 July 2021

(c) Author(s) 2021. CC BY 4.0 License.

\begin{tabular}{|c|c|c|c|c|c|c|c|c|c|}
\hline & $H A$ & 2.01 & 0.17 & 11.80 & $<<.001$ & - & - & - & - \\
\hline & $H B$ & 2.02 & 0.17 & 11.83 & $<<.001$ & - & - & - & - \\
\hline & $H D$ & 1.13 & 0.17 & 6.64 & $<<.001$ & - & - & - & - \\
\hline \multirow{11}{*}{$\begin{array}{l}\text { Source } \\
\text { (SU-UU) }\end{array}$} & $\triangle S U V A_{254}$ & & & 2.22 & 0.34 & 0.14 & 0.98 & 6.51 & 0.08 \\
\hline & $H A$ & 0.40 & 0.11 & 3.80 & 0.00 & - & - & - & - \\
\hline & $H B$ & -0.06 & 0.11 & -0.52 & 0.61 & - & - & - & - \\
\hline & $H D$ & -0.07 & 0.11 & -0.70 & 0.50 & - & - & - & - \\
\hline & $\% \triangle D O C$ & -7.06 & 2.46 & 8.22 & 0.05 & 1.13 & 0.47 & 1.53 & 0.66 \\
\hline & $\log (\% \mathrm{POC}+50)$ & -0.19 & 0.04 & 27.40 & 0.00 & 5.08 & 0.07 & 2.39 & 0.42 \\
\hline & $\% \triangle T O C$ & - & - & 2.22 & 0.34 & 1.73 & 0.37 & 0.78 & 0.80 \\
\hline & $\ln (k)$ & & & 172.43 & 0.00 & 43.21 & 0.00 & 67.84 & 0.00 \\
\hline & $H A$ & 1.69 & 0.15 & 11.60 & $<<.001$ & - & & - & \\
\hline & $H B$ & 1.90 & 0.15 & 13.04 & $<<.001$ & - & & - & \\
\hline & $H D$ & -0.28 & 0.15 & -1.89 & 0.08 & - & & - & \\
\hline \multirow{5}{*}{$\begin{array}{l}\text { Filtrate } \\
\text { (SD-SU) }\end{array}$} & $\Delta S U V A_{254}$ & - & - & 2.52 & 0.34 & 11.81 & 0.01 & 0.41 & 0.81 \\
\hline & $\% \triangle D O C$ & - & - & 0.05 & 0.87 & 2.71 & 0.21 & 2.90 & 0.42 \\
\hline & $\% \triangle \mathrm{POC}$ & - & - & 0.11 & 0.85 & 2.66 & 0.21 & 0.20 & 0.89 \\
\hline & $\% \triangle T O C$ & - & - & 0.37 & 0.75 & 2.66 & 0.21 & 0.72 & 0.80 \\
\hline & k & - & - & 0.24 & 0.81 & 20.12 & 0.00 & 0.19 & 0.88 \\
\hline \multirow{5}{*}{$\begin{array}{l}\text { Settling } \\
\text { (SS-SU) }\end{array}$} & $\triangle S U V A_{254}$ & - & - & 0.10 & 0.85 & 10.46 & 0.01 & 0.77 & 0.80 \\
\hline & $\% \triangle \mathrm{DOC}$ & - & - & 5.84 & 0.10 & 0.11 & 0.98 & 0.39 & 0.81 \\
\hline & $\% \triangle \mathrm{POC}$ & - & - & 0.38 & 0.75 & 1.08 & 0.47 & 0.21 & 0.88 \\
\hline & $\% \triangle \mathrm{TOC}$ & - & - & 0.00 & 0.96 & 1.36 & 0.43 & 0.43 & 0.81 \\
\hline & $\ln (k)$ & -0.67 & 0.07 & 81.68 & 0.00 & 11.47 & 0.01 & 2.46 & 0.42 \\
\hline
\end{tabular}

$330{ }^{\mathrm{a} F-v a l u e s}$ are reported for two-way ANOVAS, t-values are reported for follow-up pairwise t-tests

Table A2: Welch's ANOVA and follow-up games-howell pair-wise t-tests of differences between size fractions (2016 experiment). P-values for main ANOVAs are adjusted for false-discovery rate (fdr) to account for multiples outcomes tested (5 tests). Follow-up tests were only conducted when main ANOVA tests showed a significant difference. Size fractions: $\mathrm{SN}=63-2000 \mu \mathrm{m}, \mathrm{SL}=20-63 \mu \mathrm{m}, \mathrm{SMSC}=<20 \mu \mathrm{m}$.

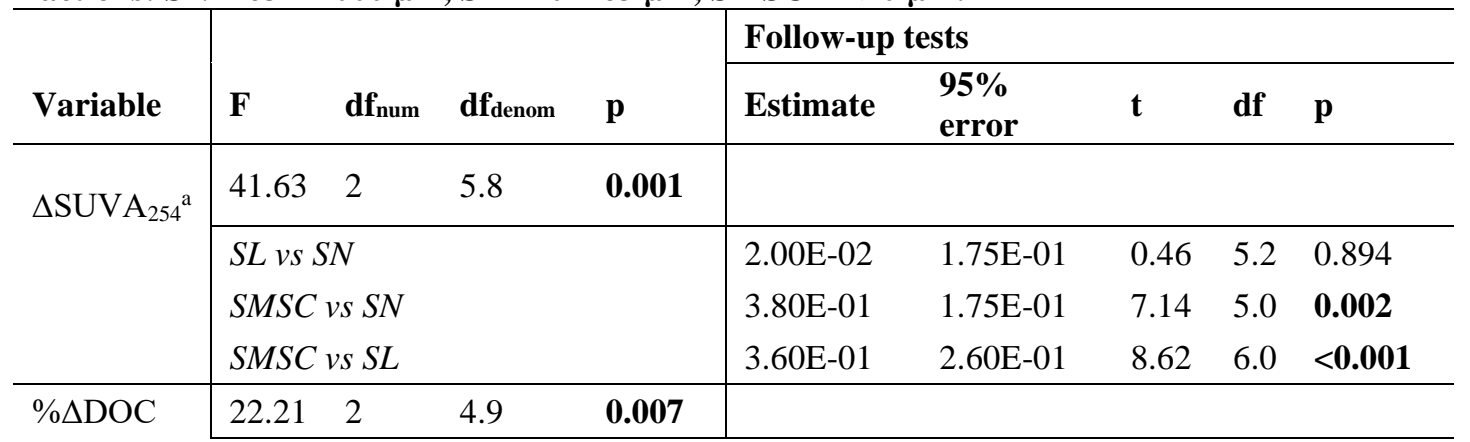




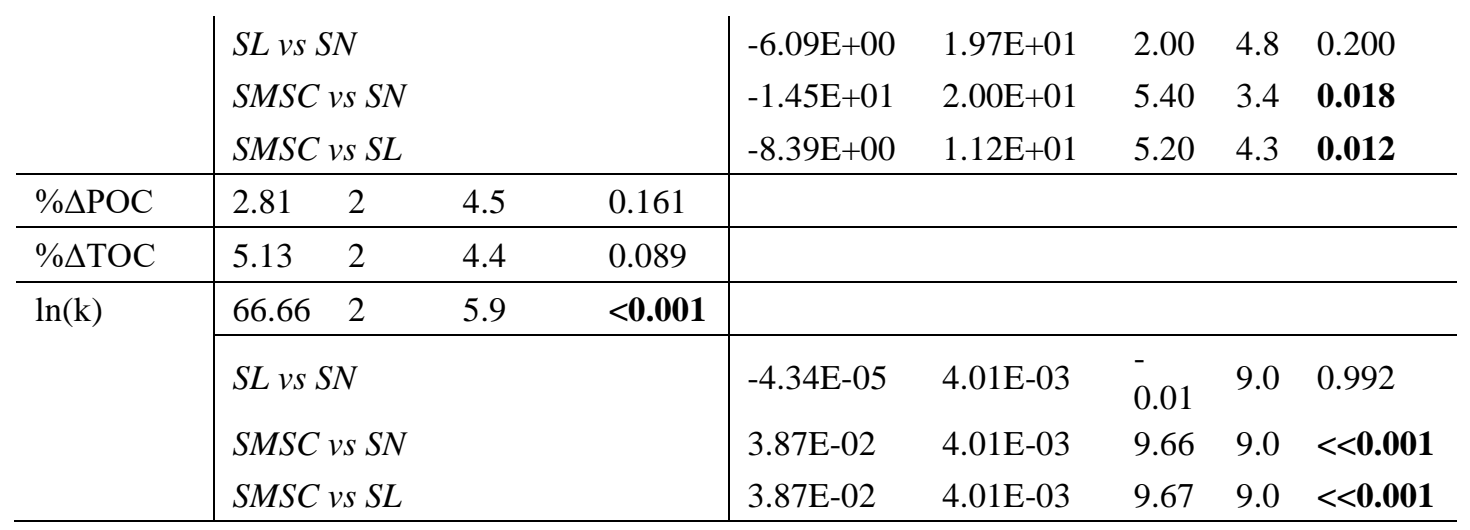

Table A3: Two-way ANOVAs for transect experiment examining effects of filtrations (unfiltered vs. filtered) and distance (immediately downstream vS. $2.79 \mathrm{~km}$ downstream) from slump SE and interactions between the two. Since multiple (4-5) parameters from the same experiment are tested, p-values were corrected for false discovery rate (FDR). Degrees of freedom associated with distance, filtration, interaction, and residuals are $1,1,1$, and 12 respectively for all tests.

\begin{tabular}{|c|c|c|c|c|c|c|c|c|c|c|c|}
\hline \multirow[t]{2}{*}{ Variable } & \multicolumn{2}{|c|}{ Distance } & \multicolumn{2}{|c|}{ Filtration } & \multicolumn{2}{|c|}{ Distance*Filtration } & \multicolumn{5}{|c|}{ Follow-up tests } \\
\hline & $\mathrm{F}$ & $\mathrm{p}$ & $\mathrm{F}$ & $\mathrm{p}$ & F & $\mathrm{p}$ & Est. & se & $\mathrm{t}$ & $\mathrm{df}$ & $\mathrm{p}$ \\
\hline$\triangle$ SUVA254 & 0.21 & 0.659 & 5.59 & 0.048 & 12.44 & 0.013 & & & & & \\
\hline $\begin{array}{l}\text { DN vs } 2.79 \mathrm{~km} \mathrm{DN} \\
\text { (filtered) } \\
\text { DN vs } 2.79 \mathrm{~km} \mathrm{DN} \\
\text { (unfiltered) }\end{array}$ & & & & & & & $\begin{array}{l}-0.09 \\
0.12\end{array}$ & $\begin{array}{l}0.04 \\
0.04\end{array}$ & $\begin{array}{l}-2.174 \\
2.815\end{array}$ & $\begin{array}{l}12 \\
12\end{array}$ & $\begin{array}{l}0.050 \\
0.016\end{array}$ \\
\hline$\% \triangle \mathrm{DOC}$ & 7.39 & 0.031 & 17.00 & 0.003 & 10.87 & 0.013 & & & & & \\
\hline $\begin{array}{l}\text { DN vs } 2.79 \mathrm{~km} \mathrm{DN} \\
\text { (filtered) } \\
\text { DN vs } 2.79 \mathrm{~km} \mathrm{DN} \\
\text { (unfiltered) }\end{array}$ & & & & & & & $\begin{array}{l}0.67 \\
-6.96\end{array}$ & $\begin{array}{l}1.64 \\
1.64\end{array}$ & $\begin{array}{l}0.409 \\
-4.253\end{array}$ & $\begin{array}{l}12 \\
12\end{array}$ & $\begin{array}{l}0.689 \\
0.001\end{array}$ \\
\hline$\% \triangle \mathrm{POC}^{\mathrm{a}}$ & 12.01 & 0.031 & - & - & - & - & & & & & \\
\hline$\% \Delta \mathrm{TOC}$ & 1.71 & 0.269 & 1.99 & 0.184 & 0.00 & 0.949 & & & & & \\
\hline $\ln (\mathrm{k})$ & 12.65 & 0.020 & 55.96 & 0.000 & 0.95 & 0.466 & & & & & \\
\hline
\end{tabular}

apercent change in POC not tested for filtration or interaction effect because negligible POC concentrations in filtered treatments 
https://doi.org/10.5194/bg-2021-150

Preprint. Discussion started: 2 July 2021

(c) Author(s) 2021. CC BY 4.0 License.

\section{Appendix B: Characterization of each size fraction}

Size fractions with lower particles sizes had lower organic matter content (lower percent organic carbon) and associated organic matter had a greater 14C age (Table B1). Extraction of size fractions was done in triplicate, but one replicate of the size fraction $>63 \mu \mathrm{m}$ had to be removed due to optical density concerns (supplementary S3.8). A biplot of PCA components 1 and 2 that explained $92 \%$ of the variation in optical indices of BEPOM revealed that extractions of organic matter in the clay and silt size fractions had a greater relative contribution of UVA humic-like peak C (Fig. B1), which has been characterized as terrigenous organic matter that has undergone less chemical reworking than peak A (Stubbins et al. 2014). While peak C was not negatively correlated with peak A, it was strongly correlated with total absorbance per unit of sediment extracted (Table S6).

Table B1: Characteristics of size fractions used in 2016 experiment. \%POC indicates POC: TSS. sd = standard deviation. SEM = standard error of the mean.

\begin{tabular}{lrrrr}
\hline Size Fraction Category & Unfractionated & $0.063-2 \mathrm{~mm}$ & $0.020-0.063 \mathrm{~mm}$ & $<0.020 \mathrm{~mm}$ \\
\hline Mean particle size & 11.9 & 48.9 & 21.67 & 5.78 \\
sd & 3.78 & 4.6 & 2.9 & 2.79 \\
\hline $\mathrm{F}^{14} \mathrm{C}$ & $\mathrm{NA}$ & 0.4113 & 0.1332 & 0.056 \\
$\mathrm{sd}$ & $\mathrm{NA}$ & 0.0019 & 0.0012 & 0.0006 \\
\hline calBP & & $8020-7926$ & $19791-19292$ & $27640-27250$ \\
(percent representation) & $\mathrm{NA}$ & $(88.3 \%)$ & $(95.4 \%)$ & $(95.4 \%)$ \\
& & $7896-7871(7.1 \%)$ & & 1.67 \\
\hline \%POC & 1.6 & 3.12 & 0.02 & 0.02 \\
SEM & 0.03 & 0.09 & & \\
\hline
\end{tabular}

$\mathrm{SL} \bullet \mathrm{SMSC} \triangle \mathrm{SN}$

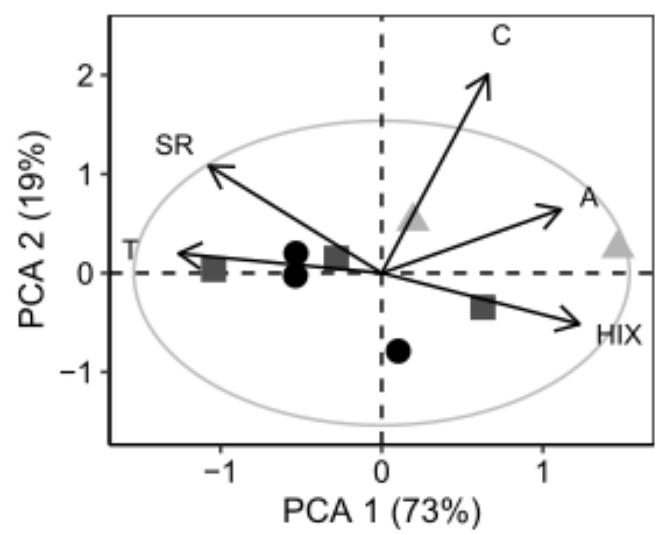

Figure A1: Principal components analysis of optical indices for BEPOM of different size fractions. PCA is shown in scaling 1. The grey circle marks the circle of equilibrium contribution. Constituent abbreviations are as in Table S5. 
https://doi.org/10.5194/bg-2021-150

Preprint. Discussion started: 2 July 2021

(c) Author(s) 2021. CC BY 4.0 License.

Appendix C: Absolute changes in SUVA254

360 Table C1: Absolute changes in SUVA 254 in 2015-16 experiments.

\begin{tabular}{clrr|ll}
\hline Year & Treatment & Site & $\Delta$ SUVA $_{254}$ & $\begin{array}{l}95 \% \\
\text { error }\end{array}$ & $\mathrm{n}$ \\
\hline 2015 & Filtered upstream (F) & HA & 0.08 & 0.36 & 3 \\
& & HB & 0.11 & 0.70 & 3 \\
& & HD & 0.02 & 0.08 & 3 \\
\cline { 2 - 6 } Unfiltered upstream (U) & HA & -0.25 & 0.20 & 3 \\
& HB & -0.06 & 0.35 & 3 \\
& HD & -0.02 & 0.44 & 3 \\
\hline Slump in filtered upstream (SU) & HA & 0.16 & 0.47 & 3 \\
& HB & -0.11 & 0.16 & 3 \\
& HD & -0.09 & 0.15 & 3 \\
\hline Slump in filtered downstream (SD) & HA & 0.20 & 0.28 & 3 \\
& HB & -0.07 & 0.06 & 3 \\
& HD & 0.04 & 0.12 & 3 \\
\cline { 2 - 6 } & HA & 0.19 & 0.41 & 3 \\
SU settle (SS) & HB & -0.05 & 0.20 & 3 \\
& HD & -0.20 & 0.60 & 2 \\
\hline Unfractionated & SE & 0.46 & 0.41 & 4 \\
2- 0.063 mm & SE & 0.06 & 0.15 & 4 \\
0.063 - 0.020 mm & SE & 0.09 & 0.10 & 4 \\
< 0.020 mm & SE & 0.45 & 0.09 & 4 \\
\hline Upstream & SE & -0.07 & 0.11 & 4 \\
Upstream filtered control & SE & -0.07 & 0.07 & 4 \\
\hline Downstream & -0.10 & 0.17 & 4 \\
Downstream filtered control & 0.07 & 0.05 & 4 \\
\hline 2.79k Downstream & -0.01 & 0.03 & 4 \\
2.79k Downstream filtered control & SE & -0.05 & 0.07 & 4 \\
\hline
\end{tabular}

\section{Code Availability}

Code for this manuscript is available upon request.

\section{Data Availability}

Data will be made openly available through the Polar Data Catalogue (CCIN reference \#: 13237). (Shakil et al. 2021) 
https://doi.org/10.5194/bg-2021-150

Preprint. Discussion started: 2 July 2021

(c) Author(s) 2021. CC BY 4.0 License.

(c) (i)

\section{Supplement link}

A supplementary pdf file has been uploaded for review with this manuscript.

\section{Author contribution}

SS and SET led the design of the study. SS led data collection, data analysis and interpretation, and manuscript writing. JEV contributed to the initial development of the idea, and JEV and SZ contributed to study design and data interpretation. SZ contributed to laboratory methods for data collection. All authors contributed to manuscript writing.

\section{Competing interests}

The authors declare they have no conflict of interest.

\section{Acknowledgements}

This work took place within the Gwich'in Settlement Region, and we are thankful for support from the Tetlit Gwich'in

375 Renwable Resources Council and Western Arctic Research Centre. We are further thankful for the field assistance of Christine Firth, Elizabeth Jerome, Andrew Koe, Joyce Kendon, Maya Guttman, Luke Gjini, and Lindsay Stephen. Maya Guttman and Joyce Kendon also helped experiment set up and sample processing. Hailey Verbonac assisted with $\mathrm{O}_{2}$ measurements during our 2015 experiments conducted in Inuvik. This manuscript also benefitted from helpful discussions with: Steve Kokelj with regards to field sampling and perspectives on landscape changes in the region; and Matthias Koschorreck and Rafael Marcé

380 with regards to chemoautotrophic processes, and Alex Wolfe who first provided advice to broaden consideration of what affects oxygen and carbon dynamics. Funding for this study was provided by the Natural Sciences and Engineering Research Council (NSERC), Polar Continental Shelf Program (Natural Resources Canada), Campus Alberta Innovates Program, ArcticNet, CiCan Cleantech Internship Program, Environment Canada Science Youth Horizons Internship, Northern Scientific Training Program, University of Alberta and UAlberta North, and the Aurora Research Institute. Personal support to SS was

385 provided by NSERC and the Garfield Weston Foundation. Research for this paper was conducted under NWT research licences: 15685 (2015); 15685 (2016); 15887 (2017); 16575 (2019).

\section{References}

Abbott, B. W., Larouche, J. R., Jones, J. B., Bowden, W. B., and Balser, A. W.: Elevated dissolved organic carbon biodegradability from thawing and collapsing permafrost, J. Geophys. Res. Biogeosciences, 119, 2049-2063, https://doi.org/10.1002/2014JG002678, 2014. 
https://doi.org/10.5194/bg-2021-150

Preprint. Discussion started: 2 July 2021

(c) Author(s) 2021. CC BY 4.0 License.

Attermeyer, K., Catalán, N., Einarsdottir, K., Freixa, A., Groeneveld, M., Hawkes, J. A., Bergquist, J., and Tranvik, L. J.: Organic Carbon Processing During Transport Through Boreal Inland Waters: Particles as Important Sites, J. Geophys. Res . Biogeosciences, 123, 2412-2428, https://doi.org/10.1029/2018JG004500, 2018.

Berggren, M., Lapierre, J.-F., and del Giorgio, P. A.: Magnitude and regulation of bacterioplankton respiratory quotient across freshwater environmental gradients, ISME J., 6, 984-993, https://doi.org/10.1038/ismej.2011.157, 2012.

Bock, E. and Wagner, M.: Oxidation of Inorganic Nitrogen Compounds as an Energy Source, in: The Prokaryotes, edited by: Rosenberg, E., DeLong, E. F., Lory, S., Stackebrandt, E., and Thompson, F., Springer Berlin Heidelberg, Berlin, Heidelberg, 83-118, https://doi.org/10.1007/978-3-642-30141-4_64, 2013.

Bröder, L., Keskitalo, K., Zolkos, S., Shakil, S., Tank, S. E., Kokelj, S. V., Tesi, T., van Dongen, B. E., Haghipour, N., Eglinton, Environ. Res. Lett., https://doi.org/10.1088/1748-9326/abee4b, 2021.

Coble, P. G.: Marine Optical Biogeochemistry: The Chemistry of Ocean Color, Chem. Rev., 107, 402-418, https://doi.org/10.1021/cr050350\%2B, 2007.

Duk-Rodkin, A., and Hughes, O. L.: Surficial geology, Fort McPherson-Bell River, Yukon-Northwest Territories. Geological

Survey of Canada, 1992.

Groeneveld, M., Catalán, N., Attermeyer, K., Hawkes, J., Einarsdóttir, K., Kothawala, D., Bergquist, J., and Tranvik, L.: Selective Adsorption of Terrestrial Dissolved Organic Matter to Inorganic Surfaces Along a Boreal Inland Water Continuum, J. Geophys. Res. Biogeosciences, 125, e2019JG005236, https://doi.org/10.1029/2019JG005236, 2020.

Hemingway, J. D., Rothman, D. H., Grant, K. E., Rosengard, S. Z., Eglinton, T. I., Derry, L. A., and Galy, V. V.: Mineral protection regulates long-term global preservation of natural organic carbon, Nature, 570, 228-231, https://doi.org/10.1038/s41586-019-1280-6, 2019.

Hugelius, G., Strauss, J., Zubrzycki, S., Harden, J. W., Schuur, E. A. G., Ping, C.-L., Schirrmeister, L., Grosse, G., Michaelson, G. J., Koven, C. D., O\&amp;apos;Donnell, J. A., Elberling, B., Mishra, U., Camill, P., Yu, Z., Palmtag, J., and Kuhry, P.: Estimated stocks of circumpolar permafrost carbon with quantified uncertainty ranges and identified data gaps, 415 Biogeosciences, 11, 6573-6593, https://doi.org/10.5194/bg-11-6573-2014, 2014.

Keskitalo, K. H., Bröder, L., Shakil, S., Zolkos, S., Tank, S. E., van Dongen, B. E., Tesi, T., Haghipour, N., Eglinton, T. I., Kokelj, S. V., and Vonk, J. E.: Downstream Evolution of Particulate Organic Matter Composition From Permafrost Thaw Slumps, Front. Earth Sci., 9, https://doi.org/10.3389/feart.2021.642675, 2021.

Klatt, J. M. and Polerecky, L.: Assessment of the stoichiometry and efficiency of CO2 fixation coupled to reduced sulfur oxidation, Front. Microbiol., 6, https://doi.org/10.3389/fmicb.2015.00484, 2015.

Kokelj, S. V., Kokoszka, J., van der Sluijs, J., Rudy, A. C. A., Tunnicliffe, J., Shakil, S., Tank, S., and Zolkos, S.: Permafrost thaw couples slopes with downstream systems and effects propagate through Arctic drainage networks, Cryosphere Discuss., 1-43, https://doi.org/10.5194/tc-2020-218, 2020.

Kothawala, D. N., Kellerman, A. M., Catalán, N., and Tranvik, L. J.: Organic Matter Degradation across Ecosystem 425 Boundaries: The Need for a Unified Conceptualization, Trends Ecol. Evol., 36, 113-122, https://doi.org/10.1016/j.tree.2020.10.006, 2021. 
https://doi.org/10.5194/bg-2021-150

Preprint. Discussion started: 2 July 2021

(c) Author(s) 2021. CC BY 4.0 License.

Lacelle, D., Fontaine, M., Pellerin, A., Kokelj, S. V., and Clark, I. D.: Legacy of Holocene Landscape Changes on Soil Biogeochemistry: A Perspective From Paleo-Active Layers in Northwestern Canada, J. Geophys. Res. Biogeosciences, 124, 2662-2679, https://doi.org/10.1029/2018JG004916, 2019.

430 Lenth, R. V.: emmeans: Estimated Marginal Means, aka Least-Squares Means. R package version 1.6.0. https://CRAN.Rproject.org/package=emmeans, 2021.

Littlefair, C. A. and Tank, S. E.: Biodegradability of Thermokarst Carbon in a Till-Associated, Glacial Margin Landscape: The Case of the Peel Plateau, NWT, Canada, J. Geophys. Res. Biogeosciences, 123, 3293-3307, https://doi.org/10.1029/2018JG004461, 2018.

435 Littlefair, C. A., Tank, S. E., and Kokelj, S. V.: Retrogressive thaw slumps temper dissolved organic carbon delivery to streams of the Peel Plateau, NWT, Canada, Biogeosciences, 14, 5487-5505, https://doi.org/10.5194/bg-14-5487-2017, 2017.

Mann, P. J., Eglinton, T. I., McIntyre, C. P., Zimov, N., Davydova, A., Vonk, J. E., Holmes, R. M., and Spencer, R. G. M.: Utilization of ancient permafrost carbon in headwaters of Arctic fluvial networks, Nat. Commun., 6, 7856, https://doi.org/10.1038/ncomms8856, 2015.

440 Nelson, D. C., Jørgensen, B. B., and Revsbech, N. P.: Growth Pattern and Yield of a Chemoautotrophic Beggiatoa sp. in Oxygen-Sulfide Microgradients, Appl. Environ. Microbiol., 52, 225-233, 1986.

Olefeldt, D., Goswami, S., Grosse, G., Hayes, D., Hugelius, G., Kuhry, P., McGuire, A. D., Romanovsky, V. E., Sannel, A. B. K., Schuur, E. A. G., and Turetsky, M. R.: Circumpolar distribution and carbon storage of thermokarst landscapes, Nat. Commun., 7, 13043, https://doi.org/10.1038/ncomms13043, 2016.

445 Opfergelt, S.: The next generation of climate model should account for the evolution of mineral-organic interactions with permafrost thaw, Environ. Res. Lett., 15, 091003, https://doi.org/10.1088/1748-9326/ab9a6d, 2020.

Osburn, C. L., Handsel, L. T., Mikan, M. P., Paerl, H. W., and Montgomery, M. T.: Fluorescence Tracking of Dissolved and Particulate Organic Matter Quality in a River-Dominated Estuary, Environ. Sci. Technol., 46, 8628-8636, https://doi.org/10.1021/es3007723, 2012.

450 Percak-Dennett, E., He, S., Converse, B., Konishi, H., Xu, H., Corcoran, A., Noguera, D., Chan, C., Bhattacharyya, A., Borch, T., Boyd, E., and Roden, E. E.: Microbial acceleration of aerobic pyrite oxidation at circumneutral pH, Geobiology, 15, 690703, https://doi.org/10.1111/gbi.12241, 2017.

Peter, S., Isidorova, A., and Sobek, S.: Enhanced carbon loss from anoxic lake sediment through diffusion of dissolved organic carbon, J. Geophys. Res. Biogeosciences, 121, 1959-1977, https://doi.org/10.1002/2016JG003425, 2016.

455 Richardson, D. C., Newbold, J. D., Aufdenkampe, A. K., Taylor, P. G., and Kaplan, L. A.: Measuring heterotrophic respiration rates of suspended particulate organic carbon from stream ecosystems: Measuring respiration rates of POC, Limnol. Oceanogr. Methods, 11, 247-261, https://doi.org/10.4319/lom.2013.11.247, 2013.

Schuur, E. A. G., McGuire, A. D., Schädel, C., Grosse, G., Harden, J. W., Hayes, D. J., Hugelius, G., Koven, C. D., Kuhry, P., Lawrence, D. M., Natali, S. M., Olefeldt, D., Romanovsky, V. E., Schaefer, K., Turetsky, M. R., Treat, C. C., and Vonk, J. E.: Climate change and the permafrost carbon feedback, Nature, 520, 171-179, https://doi.org/10.1038/nature14338, 2015.

Segal, R. A., Lantz, T. C., and Kokelj, S. V.: Acceleration of thaw slump activity in glaciated landscapes of the Western Canadian Arctic, Environ. Res. Lett., 11, 034025, https://doi.org/10.1088/1748-9326/11/3/034025, 2016. 
https://doi.org/10.5194/bg-2021-150

Preprint. Discussion started: 2 July 2021

(c) Author(s) 2021. CC BY 4.0 License.

Shakil, S., Tank, S. E., Kokelj, S. V., Vonk, J. E., and Zolkos, S.: Particulate dominance of organic carbon mobilization from thaw slumps on the Peel Plateau, NT: Quantification and implications for stream systems and permafrost carbon release, Environ. Res. Lett., 15, 114019, https://doi.org/10.1088/1748-9326/abac36, 2020.

Shakil, S., Tank, S., Vonk J.E., and Zolkos S.: Incubation Data Assessing Biodegradability of Organic Carbon Mobilized from Permafrost Thaw Slumps (Peel Plateau, NT, Canada). Waterloo, Canada: Canadian Cryospheric Information Network (CCIN). (DOI TBD), 2021.

Sinha, B. and Annachhatre, A. P.: Partial nitrification-operational parameters and microorganisms involved, Rev. Environ. Sci. Biotechnol., 6, 285-313, https://doi.org/10.1007/s11157-006-9116-x, 2007.

Spona-Friedl, M., Braun, A., Huber, C., Eisenreich, W., Griebler, C., Kappler, A., and Elsner, M.: Substrate-dependent CO2 fixation in heterotrophic bacteria revealed by stable isotope labelling, FEMS Microbiol. Ecol., 96, fiaa080, https://doi.org/10.1093/femsec/fiaa080, 2020.

Stolper, D. A., Revsbech, N. P., and Canfield, D. E.: Aerobic growth at nanomolar oxygen concentrations, Proc. Natl. Acad. Sci., 107, 18755-18760, https://doi.org/10.1073/pnas.1013435107, 2010.

Tank, S. E., Vonk, J. E., Walvoord, M. A., McClelland, J. W., Laurion, I., and Abbott, B. W.: Landscape matters: Predicting the biogeochemical effects of permafrost thaw on aquatic networks with a state factor approach, Permafr. Periglac. Process., 31, 358-370, https://doi.org/10.1002/ppp.2057, 2020.

Tanski, G., Lantuit, H., Ruttor, S., Knoblauch, C., Radosavljevic, B., Strauss, J., Wolter, J., Irrgang, A. M., Ramage, J., and 480 Fritz, M.: Transformation of terrestrial organic matter along thermokarst-affected permafrost coasts in the Arctic, Sci. Total Environ., 581-582, 434-447, https://doi.org/10.1016/j.scitotenv.2016.12.152, 2017.

Tanski, G., Wagner, D., Knoblauch, C., Fritz, M., Sachs, T., and Lantuit, H.: Rapid CO2 Release From Eroding Permafrost in Seawater, Geophys. Res. Lett., 46, 11244-11252, https://doi.org/10.1029/2019GL084303, 2019.

Tesi, T., Semiletov, I., Dudarev, O., Andersson, A., and Gustafsson, Ö.: Matrix association effects on hydrodynamic sorting and degradation of terrestrial organic matter during cross-shelf transport in the Laptev and East Siberian shelf seas, J. Geophys. Res. Biogeosciences, 121, 731-752, https://doi.org/10.1002/2015JG003067, 2016.

Turetsky, M. R., Abbott, B. W., Jones, M. C., Anthony, K. W., Olefeldt, D., Schuur, E. A. G., Grosse, G., Kuhry, P., Hugelius, G., Koven, C., Lawrence, D. M., Gibson, C., Sannel, A. B. K., and McGuire, A. D.: Carbon release through abrupt permafrost thaw, Nat. Geosci., 13, 138-143, https://doi.org/10.1038/s41561-019-0526-0, 2020.

490 Vachon, D., Sadro, S., Bogard, M. J., Lapierre, J.-F., Baulch, H. M., Rusak, J. A., Denfeld, B. A., Laas, A., Klaus, M., Karlsson, J., Weyhenmeyer, G. A., and Giorgio, P. A. del: Paired O2-CO2 measurements provide emergent insights into aquatic ecosystem function, Limnol. Oceanogr. Lett., 5, 287-294, https://doi.org/10.1002/lol2.10135, 2020.

Vonk, J. E., Tank, S. E., Mann, P. J., Spencer, R. G. M., Treat, C. C., Striegl, R. G., Abbott, B. W., and Wickland, K. P.: Biodegradability of dissolved organic carbon in permafrost soils and aquatic systems: a meta-analysis, Biogeosciences, 12 , 6915-6930, https://doi.org/10.5194/bg-12-6915-2015, 2015a.

Vonk, J. E., Tank, S. E., Bowden, W. B., Laurion, I., Vincent, W. F., Alekseychik, P., Amyot, M., Billet, M. F., Canário, J., Cory, R. M., Deshpande, B. N., Helbig, M., Jammet, M., Karlsson, J., Larouche, J., MacMillan, G., Rautio, M., Walter Anthony, K. M., and Wickland, K. P.: Reviews and syntheses: Effects of permafrost thaw on Arctic aquatic ecosystems, Biogeosciences, 12, 7129-7167, https://doi.org/10.5194/bg-12-7129-2015, 2015 b. 
https://doi.org/10.5194/bg-2021-150

Preprint. Discussion started: 2 July 2021

(c) Author(s) 2021. CC BY 4.0 License.

(c) (1)

500 Weishaar, J. L., Aiken, G. R., Bergamaschi, B. A., Fram, M. S., Fujii, R., and Mopper, K.: Evaluation of Specific Ultraviolet Absorbance as an Indicator of the Chemical Composition and Reactivity of Dissolved Organic Carbon, Environ. Sci. Technol., 37, 4702-4708, https://doi.org/10.1021/es030360x, 2003.

Wologo, E., Shakil, S., Zolkos, S., Textor, S., Ewing, S., Klassen, J., Spencer, R. G. M., Podgorski, D. C., Tank, S. E., Baker, M. A., O’Donnell, J. A., Wickland, K. P., Foks, S. S. W., Zarnetske, J. P., Lee-Cullin, J., Liu, F., Yang, Y., Kortelainen, P.,

505 Kolehmainen, J., Dean, J. F., Vonk, J. E., Holmes, R. M., Pinay, G., Powell, M. M., Howe, J., Frei, R. J., Bratsman, S. P., and Abbott, B. W.: Stream Dissolved Organic Matter in Permafrost Regions Shows Surprising Compositional Similarities but Negative Priming and Nutrient Effects, Glob. Biogeochem. Cycles, 35, e2020GB006719, https://doi.org/10.1029/2020GB006719, 2021.

Zar, J. H.: Biostatistical Analysis, 5th ed., Prentice Hall, Upper Saddle River, N.J., 944 pp., 2010.

510 Zolkos, S. and Tank, S. E.: Experimental Evidence That Permafrost Thaw History and Mineral Composition Shape Abiotic Carbon Cycling in Thermokarst-Affected Stream Networks, Front. Earth Sci., 8, https://doi.org/10.3389/feart.2020.00152, 2020 .

Zolkos, S., Tank, S. E., and Kokelj, S. V.: Mineral Weathering and the Permafrost Carbon-Climate Feedback, Geophys. Res. Lett., 45, 9623-9632, https://doi.org/10.1029/2018GL078748, 2018.

515 Zolkos, S., Tank, S. E., Striegl, R. G., and Kokelj, S. V.: Thermokarst Effects on Carbon Dioxide and Methane Fluxes in Streams on the Peel Plateau (NWT, Canada), J. Geophys. Res. Biogeosciences, 124, 1781-1798, https://doi.org/10.1029/2019JG005038, 2019.

Zolkos, S., Tank, S. E., Striegl, R. G., Kokelj, S. V., Kokoszka, J., Estop-Aragonés, C., and Olefeldt, D.: Thermokarst amplifies fluvial inorganic carbon cycling and export across watershed scales on the Peel Plateau, Canada, Biogeosciences, 17, 51635182, https://doi.org/10.5194/bg-17-5163-2020, 2020. 